\title{
Relative effectiveness of organic and inorganic nutrient sources in improving yield, seed quality and nutrient uptake of canola
}

\author{
S. S. Malhi ${ }^{1}$, C. L. Vera ${ }^{2}$, S. A. Brandt ${ }^{1}$ \\ ${ }^{1}$ Northeast Agricultural Research Foundation, Melfort, Canada; ssmalhica@yahoo.ca \\ ${ }^{2}$ Agriculture and Agri-Food Canada, Research Farm, Melfort, Canada; ${ }^{*}$ Corresponding Author: cecil.vera@agr.gc.ca \\ Received 15 August 2013; revised 17 October 2013; accepted 12 November 2013 \\ Copyright (C) 2013 S. S. Malhi et al. This is an open access article distributed under the Creative Commons Attribution License, \\ which permits unrestricted use, distribution, and reproduction in any medium, provided the original work is properly cited.
}

\section{ABSTRACT}

The proper use of organic and inorganic nutrient sources is important to sustain high levels of crop production, while maintaining or enhancing soil and environmental quality. A 4-year (2009 to 2012) field experiment was established in spring 2009 on a Gray Luvisol (Typic Haplocryalf) loam soil at Star City, Saskatchewan, Canada, to determine the effectiveness of organic/biological (compost, wood ash [fine and granular], alfalfa pellets, distiller grain, thin stillage, glycerol, fish food additive, Penicillium bilaiae), inorganic/mineral (granular-gypsum, rapid release elemental S [RRES], rock phosphate [granular and fine]) and chemical/synthetic (granular-ammonium nitrate, triple super phosphate and potassium sulphate) nutrient sources (amendments/chemicals) in improving seed yield, straw yield, seed quality and nutrient uptake ( $N, P, K$ and $S$ ) in seed + straw of canola. Combined application of $N, P$ and $S$ chemical fertilizers (NPS) produced considerably greater seed yield, straw yield and nutrient uptake of canola compared to the unamended control in all four years. In treatments receiving only organic amendments, thin stillage produced the greatest seed yield, straw yield and nutrient uptake in all years, and it was similar to the NPS balanced fertilizer treatment, while fish food additive and distiller grain dry of wheat in 2009, 2011 and 2012, distiller grain dry of corn in 2009 and 2012, and compost and alfalfa pellets in 2011 and 2012 produced significantly greater seed yield, straw yield and nutrient uptake, when compared to the control. In treatments where chemical fertilizers were also applied, in addition to organic amendments, ap- plication of $\mathbf{N}$ fertilizer increased seed yield, straw yield and nutrient uptake substantially when combined with wood ash fine in 2009, 2010, 2011 and 2012, wood ash granular in 2009, 2011 and 2012, and glycerol in 2009 and 2012 (moderate increase in 2012). In the chemical fertilizer treatments, there was a reduction in seed yield, straw yield and nutrient uptake of canola when only $\mathbf{N}$ fertilizer was applied compared to the control (significant in 2010 and 2011). Application of $P$ along with N (NP) increased seed yield, straw yield and nutrient uptake of canola compared to $\mathrm{N}$ alone treatment, but was less than the NPS treatment in all years. Application of $S$ along with N (NS) increased seed yield, straw yield and nutrient uptake of canola further compared to the NP treatment, but it was still lower than the NPS treatment in 2010 and 2011. In treatments receiving inorganic/mineral amendments in addition to chemical fertilizers, application of $\mathbf{N}+\mathbf{P}$ fertilizers substantially increased seed yield, straw yield and nutrient uptake in treatments receiving gypsum and RRES in 2009, 2010, 2011 and 2012. This suggests the potential of gypsum and RRES in preventing $S$ deficiency in organic crops when grown on S-deficient soils, provided other nutrients are not limiting in the soil for crop growth. Seed yield, straw yield and nutrient uptake with application of $\mathrm{N}$ and $\mathrm{S}$ fertilizers in combination with rock phosphate and/or Penicillium bilaiae were similar to $\mathrm{N}+\mathrm{S}$ treatment in most cases, except in 2011 when application of finely-ground or powder rock phosphate in a combination with $\mathrm{N}+\mathrm{S}$ produced significantly greater yield and nutrient uptake than $\mathrm{N}+\mathrm{S}$ with granular rock phosphate. This suggests little contribution of rock phosphate 
and/or Penicillium bilaiae in improving yield and nutrient uptake of canola, and improves the performance of fine rock phosphate only evident in the third growing season in 2011, after three consecutive applications, but not in 2012. In conclusion, some organic amendments showed potential for improvement in organic crop production, and in some other cases highest yield and nutrient uptake were produced when organic amendments were applied in combination with chemical fertilizers, or from combined application of chemical $N, S$ and $P$ fertilizers. The implications of these findings are that the use of some organic amendments can be feasible for improving crop yields under organic production. These findings also suggest the potential of some inorganic amendments (e.g., RRES and gypsum) in preventing $S$ deficiency in organic crops, provided other nutrients are not limiting in the soil.

Keywords: Inorganic; Nutrient Sources; Nutrient Uptake; Organic; Seed Quality; Yield

\section{INTRODUCTION}

Any nutrient(s) limiting in soil can cause a substantial reduction in crop yield. In the Canadian Prairies, most soils are deficient in available N, many are low in available $\mathrm{P}$, and some contain insufficient amounts of available S (like many Gray and Dark Gray soils in the Parkland region) and $\mathrm{K}$ for optimum crop growth and yield, especially under organic agriculture [1-3]. Nutrient deficiencies in crops can be prevented by using organic and inorganic nutrient sources. Chemical fertilizers, because of their huge yield response, easy availability, and convenient transportation and application, are very attractive and commonly used to enhance crop production [4-7]. However, it is possible that the long-term use of increased amounts of only chemical fertilizers may degrade soil structure and deteriorate productive capacity of soils $[8,9]$. On the other hand, sole application of organic nutrient sources may not be able to maintain and synchronize the required supply of nutrients to the growing plants for optimum crop production, because of relatively less quantity of plant-available nutrients and more time needed for mineralization to release nutrients for effective plant uptake [10-17]. Judicious/proper use of organic and inorganic nutrient sources is important to decrease the sole dependence on chemical fertilizers for sustainable high crop production by minimizing nutrient losses to the environment and optimizing nutrient use efficiency [18-23]. Integrated/combined use of organic and inorganic amendments or chemicals may be a way to ensure high sustainable soil productivity, fertility and quality, and environmental quality [22,24-30].

In the semi-arid region of the Canadian Prairies, maintaining soil fertility is an important production issue facing organic agriculture [2]. The $\mathrm{N}$ deficiency in soils on organic farms can be minimized by growing $\mathrm{N}$-fixing legume crops in the rotations as grain or green manure crops [31-37]. However in soils deficient in available P, $\mathrm{K}, \mathrm{S}$ or other essential nutrients, the only alternative is to use external nutrient sources because synthetic fertilizers/chemicals cannot be applied to prevent nutrient deficiencies and increase yield in organic crops. Manure/ compost and some other organic amendments can provide these nutrients, but often there is not enough manure to apply on all farm fields, or the high cost of transportation of low nutrient content manure makes their use uneconomic [38-44]. On such soils, rock phosphate fertilizer, elemental S fertilizer, gypsum, wood ash (a waste product of forest industry) or other amendments may be useful to correct deficiencies of these nutrients.

The information on the relative comparisons of organic and inorganic nutrient sources in preventing nutrient deficiencies in the same experiment is lacking, especially in the Parkland region of Canada. The objective of this study was to determine the relative effectiveness of organic and inorganic nutrient sources (amendments/ chemicals), and their combined applications in preventing nutrient deficiencies in crops, and increasing crop yield, seed quality and nutrient uptake.

\section{MATERIALS AND METHODS}

The 4-year (2009 to 2012) field experiment was established in the spring of 2009 on a Gray Luvisol (Typic Haplocryalf) loam soil near Star City, Saskatchewan. Soil at this site has shown severe S deficiency in canola in previous years [45], and significant increase in forage yield of timothy from S application as well as non-significant increase in forage yield of timothy from $\mathrm{P}$ application [46]. Some characteristics of soils used in this experiment are presented in Table 1. Precipitation in the growing season (May, June, July and August) at the nearest Environment Canada Meteorological Station (AAFC Melfort Research Farm) is given in Table 2.

A randomized complete block design was used to lay out the treatments in four replications. Each plot was 7.5 $\mathrm{m}$ long and $1.8 \mathrm{~m}$ wide. There were 31 treatments (except Treatments 27,30 and 31 missing in 2009, and Treatments 24 and 25 missing in 2012): 1. Control (no amendment); 2. Compost @ $20 \mathrm{Mg} \cdot \mathrm{ha}^{-1}$; 3. Wood ash fine@2 $2 \mathrm{Mg} \cdot \mathrm{ha}^{-1} ; 4$. Alfalfa pellets @ $2 \mathrm{Mg} \cdot \mathrm{ha}^{-1} ; 5$. Alfalfa + canola meal pellets@ $2 \mathrm{Mg} \cdot \mathrm{ha}^{-1} ; 6$. Distiller grain (wheat) - wet@2 $\mathrm{Mg} \cdot \mathrm{ha}^{-1} ; 7$. Distiller grain (wheat) - dry@1 Mg·ha ${ }^{-1} ; 8$. Thin stillage @ 20,000 $\mathrm{L} \cdot \mathrm{ha}^{-1} ; 9$. Glycerol @ $1 \mathrm{Mg} \cdot \mathrm{ha}^{-1} ; \mathbf{1 0}$. Fish food additive (a) $1 \mathrm{Mg} \cdot \mathrm{ha}^{-1} ; 11$. Triple super phosphate $(0-45-0) @$ 
Table 1. Some characteristics of soil in spring 2009 at initiation of the field experiment at Star City, Saskatchewan.

\begin{tabular}{|c|c|c|c|c|c|c|c|c|c|}
\hline Site & $\begin{array}{c}\text { Soil } \\
\text { Great } \\
\text { Group* }\end{array}$ & Depth $(\mathrm{cm})$ & Texture & $\begin{array}{l}\text { Organic } \\
\text { matter (\%) }\end{array}$ & $\begin{array}{c}\mathrm{pH} \\
(1: 2 \text { water })\end{array}$ & $\begin{array}{l}\text { Nitrate-N } \\
\left(\mathrm{mg} \cdot \mathrm{kg}^{-1}\right)\end{array}$ & $\begin{array}{l}\text { Extractable P } \\
\left(\mathrm{mg} \cdot \mathrm{kg}^{-1}\right)\end{array}$ & $\begin{array}{c}\mathrm{SO}_{4}-\mathrm{S} \\
\left(\mathrm{mg} \cdot \mathrm{kg}^{-1}\right)\end{array}$ & $\begin{array}{l}\text { Extractable } \mathrm{K} \\
\left(\mathrm{mg} \cdot \mathrm{kg}^{-1}\right)\end{array}$ \\
\hline \multirow[t]{3}{*}{ StarCity } & Gray Luvisol & $0-15$ & & 3.1 & 6.6 & 7.5 & 13.9 & 4.5 & 202 \\
\hline & & $15-30$ & & & & 2.4 & 9.6 & 2.3 & 146 \\
\hline & & $30-60$ & & & & 3.0 & 7.8 & 1.6 & 180 \\
\hline
\end{tabular}

*Based on Canadian Soil Classification System.

Table 2. Growing season monthly and total precipitation for the four site-years, and average 30-yr average precipitation and temperature at Star City, Saskatchewan.

\begin{tabular}{ccccccc}
\hline \multirow{2}{*}{ Month } & \multicolumn{3}{c}{ Precipitation in the growing season $(\mathrm{mm})^{*}$} & \multicolumn{2}{c}{ 30-yr average (Melfort Research Farm) } \\
\cline { 2 - 6 } & 2009 & 2010 & 2011 & 2012 & Precipitation $(\mathrm{mm})$ & Temperature $\left({ }^{\circ} \mathrm{C}\right)$ \\
\hline May & 21.2 & 66.6 & 10.5 & 72.7 & 45.6 & 9.1 \\
June & 46.6 & 113.2 & 103.5 & 112.3 & 65.8 & 16.9 \\
July & 75.6 & 63.6 & 73.3 & 97.8 & 75.5 & 18.3 \\
August & 81.6 & 56.8 & 10.7 & 68.1 & 56.8 & 19.6 \\
Total & 225.0 & 300.2 & 198.0 & 350.9 & 243.7 & \\
\hline
\end{tabular}

${ }^{*}$ At the nearest Environment Canada Meteorological Station (Melfort Research Farm).

$20 \mathrm{~kg} \cdot \mathrm{P} \cdot \mathrm{ha}^{-1}+$ ammonium nitrate (34-0-0) @ 80 $\mathrm{kg} \cdot \mathrm{N} \cdot \mathrm{ha}^{-1}+$ potassium sulfate $(0-0-51-17) @ 20$ $\mathrm{kg} \cdot \mathrm{S} \cdot \mathrm{ha}^{-1} ;$ 12. Penicillium bilaiae $+80 \mathrm{~kg} \cdot \mathrm{N} \cdot \mathrm{ha}^{-1}+20$ $\mathrm{kg} \cdot \mathrm{S} \cdot \mathrm{ha}^{-1} ; 13$. Rock phosphate granular (International Compost)@20 kg.P.ha ${ }^{-1}+80 \mathrm{~kg} \cdot \mathrm{N} \cdot \mathrm{ha}^{-1}+20 \mathrm{~kg} \cdot \mathrm{S} \cdot \mathrm{ha}^{-1}$; 14. Rock phosphate finely-ground (International Compost) @ $20 \mathrm{~kg} \cdot \mathrm{P} \cdot \mathrm{ha}^{-1}+80 \mathrm{~kg} \cdot \mathrm{N} \cdot \mathrm{ha}^{-1}+20 \mathrm{~kg} \cdot \mathrm{S} \cdot \mathrm{ha}^{-1} ; 15$. Rock phosphate granular (BC Mines) @ $20 \mathrm{~kg} \cdot \mathrm{P} \cdot \mathrm{ha}^{-1}+$ $80 \mathrm{~kg} \cdot \mathrm{N} \cdot \mathrm{ha}^{-1}+20 \mathrm{~kg} \cdot \mathrm{S} \cdot \mathrm{ha}^{-1} ; \mathbf{1 6}$. Rock phosphate finelyground (BC Mines) @ $20 \mathrm{~kg} \cdot \mathrm{P} \cdot \mathrm{ha}^{-1}+80 \mathrm{~kg} \cdot \mathrm{N} \cdot \mathrm{ha}^{-1}+20$ $\mathrm{kg} \cdot \mathrm{S} \cdot \mathrm{ha}^{-1} ;$ 17. Gypsum@20 kg $\cdot \mathrm{S} \cdot \mathrm{ha}^{-1}+80 \mathrm{~kg} \cdot \mathrm{N} \cdot \mathrm{ha}^{-1}+$ $20 \mathrm{~kg} \cdot \mathrm{P} \cdot \mathrm{ha}^{-1}$; 18. Rapid release elemental S (RRES) @ $20 \mathrm{~kg} \cdot \mathrm{S} \cdot \mathrm{ha}^{-1}+80 \mathrm{~kg} \cdot \mathrm{N} \cdot \mathrm{ha}^{-1}+20 \mathrm{~kg} \cdot \mathrm{P} \cdot \mathrm{ha}^{-1} ; \mathbf{1 9}$. Glycerol @ $1 \mathrm{Mg} \cdot \mathrm{ha}^{-1}+80 \mathrm{~kg} \cdot \mathrm{N} \cdot \mathrm{ha}^{-1} ; \mathbf{2 0}$. Wood ash - fine (a) $2 \mathrm{Mg} \cdot \mathrm{ha}^{-1}+80 \mathrm{~kg} \cdot \mathrm{N} \cdot \mathrm{ha}^{-1} ; \mathbf{2 1}$. Distiller grain (corn) dry @ $1 \mathrm{Mg} \cdot \mathrm{ha}^{-1} ; \mathbf{2 2}$. Treatment $15+$ Penicillium bilaiae; 23. Treatment $16+$ Penicillium bilaiae; 24. Rock phosphate + humates granular (BC Mines) @ $20 \mathrm{~kg} \cdot \mathrm{P} \cdot \mathrm{ha}^{-1}+$ $80 \mathrm{~kg} \cdot \mathrm{N} \cdot \mathrm{ha}^{-1}+20 \mathrm{~kg} \cdot \mathrm{S} \cdot \mathrm{ha}^{-1} ; 25$. Treatment $24+$ Penicillium bilaiae; 26. Rock phosphate [powder] (BC Mines) (a) $20 \mathrm{~kg} \cdot \mathrm{P} \cdot \mathrm{ha}^{-1}+80 \mathrm{~kg} \cdot \mathrm{N} \cdot \mathrm{ha}^{-1}+20 \mathrm{~kg} \cdot \mathrm{S} \cdot \mathrm{ha}^{-1} ; \mathbf{2 7 .} \mathrm{N}+$ $\mathrm{S}-80 \mathrm{~kg} \cdot \mathrm{N} \cdot \mathrm{ha}^{-1}+20 \mathrm{~kg} \cdot \mathrm{S} \cdot \mathrm{ha}^{-1} ; \mathbf{2 8}$. Wood ash - granular @ $200 \mathrm{~kg} \cdot \mathrm{ha}^{-1}$ (applied side band); 29. Wood ash granular@200 kg.ha ${ }^{-1}$ (applied side band) + 80 $\mathrm{kg} \cdot \mathrm{N} \cdot \mathrm{ha}^{-1} ; 30 . \mathrm{N}+\mathrm{P}-80 \mathrm{~kg} \cdot \mathrm{N} \cdot \mathrm{ha}^{-1}+20 \mathrm{~kg} \cdot \mathrm{P} \cdot \mathrm{ha}^{-1}$; and 31. $\mathrm{N}$ only $-80 \mathrm{~kg} \cdot \mathrm{N} \cdot \mathrm{ha}^{-1}$. Estimated amounts of $\mathrm{N}, \mathrm{P}, \mathrm{K}$ or $\mathrm{S}$ applied annually in various treatments are presented in Table 3. In 2009, N only ( $\operatorname{Tr} 31)$, NP (Tr 30) and NS (Tr 27) treatments were not applied. In 2012, we could not obtain rock phosphate + humates granular fertilizer, so Treatments 24 and 25 did not receive any amendments in 2012. Amendments were broadcast on surface and then incorporated to about $10 \mathrm{~cm}$ soil depth a few days prior to seeding. Plots were seeded with a double-disc press drill at $17.8 \mathrm{~cm}$ row spacing. Data were collected on seed and straw yield, and on concentration of total $\mathrm{N}$, $\mathrm{P}, \mathrm{K}$ and $\mathrm{S}$ in seed and straw. Seed yield was determined by combine harvesting a $7 \mathrm{~m}$ long and $1.2 \mathrm{~m}$ wide strip in each plot. Seed and straw samples were oven dried $\left(60^{\circ} \mathrm{C}\right)$, and analyzed for total $\mathrm{N}$ [47], total P [48], total $\mathrm{K}$ [49] and total S [50] to calculate total N, P, K and S uptake in seed and straw by multiplying seed or straw yields by the concentrations of these nutrients in seed or straw.

The data on each parameter were subjected to analyses of variance (ANOVA) using GLM procedure in SAS [51]. The least significant difference at $\mathrm{P} \leq 0.05\left(\mathrm{LSD}_{0.05}\right)$ was used to determine significant differences between treatment means.

\section{RESULTS}

\subsection{Weather Conditions}

The growing season precipitation (GSP) was near long-term average in 2009, with slightly lower than average precipitation in May and slightly higher than average precipitation in August (Table 2). In 2010 and 2012, the GSP was much higher than average (especially in June), and relatively cooler air temperatures in the summer. In 2011, the GSP was below average (especially in May during seeding season and in August during seed formation/filling), with relatively cooler air temperatures and wet conditions in June, and relatively warmer/hotter air temperatures and dry moisture conditions in late July 
Table 3. Estimated amounts of N, P, K or S applied annually in different treatments at Star City, Saskatchewan.

\begin{tabular}{|c|c|c|c|c|c|}
\hline \multicolumn{2}{|r|}{ Treatment } & \multicolumn{4}{|c|}{$\mathrm{kg} \cdot \mathrm{ha}^{-1} \mathrm{yr}^{-1}$} \\
\hline No & Amendments & $\mathrm{N}$ & $\mathrm{P}$ & $\mathrm{K}$ & $\mathrm{S}$ \\
\hline 1 & Control (no amendment) & 0 & 0 & 0 & 0 \\
\hline 2 & Compost@20 Mg·ha ${ }^{-1}$ & 260 & 128 & 260 & 60 \\
\hline 3 & Wood ash - fine@ $2 \mathrm{Mg} \cdot \mathrm{ha}^{-1}$ & 0 & 10 & 90 & 26 \\
\hline 28 & Wood ash - granular @ $200 \mathrm{~kg} \cdot \mathrm{ha}^{-1}$ (applied side band) & 0 & 1 & 9 & 3 \\
\hline 4 & Alfalfa pellets@2 Mg $\cdot \mathrm{ha}^{-1}$ & 58 & 4 & 50 & 4 \\
\hline 5 & Alfalfa + canola meal pellets@2 Mg $\cdot \mathrm{ha}^{-1}$ & 42 & 3 & 28 & 4 \\
\hline 6 & Distiller grain (wheat) - wet @ $2 \mathrm{Mg} \cdot \mathrm{ha}^{-1}$ & 111 & 19 & 24 & 8 \\
\hline 7 & Distiller grain (wheat) - dry @ $1 \mathrm{Mg} \cdot \mathrm{ha}^{-1}$ & 56 & 8 & 11 & 7 \\
\hline 21 & Distiller grain (corn) - dry @ $1 \mathrm{Mg} \cdot \mathrm{ha}^{-1}$ & 49 & 8 & 11 & 7 \\
\hline 8 & Thin stillage @ 20,000 L·ha ${ }^{-1}$ & 100 & 22 & 32 & 10 \\
\hline 9 & Glycerol@1 Mg·ha ${ }^{-1}$ & $\mathrm{ND}^{*}$ & ND & ND & ND \\
\hline 10 & Fish food additive@ $1 \mathrm{Mg} \cdot \mathrm{ha}^{-1}$ & 97 & 8 & 4 & 7 \\
\hline 17 & Gypsum @ $20 \mathrm{~kg} \cdot \mathrm{S} \cdot \mathrm{ha}^{-1}+80 \mathrm{~kg} \cdot \mathrm{N} \cdot \mathrm{ha}^{-1}+20 \mathrm{~kg} \cdot \mathrm{P} \cdot \mathrm{ha}^{-1}$ & 80 & 20 & 0 & 20 \\
\hline 18 & Rapid release elemental S @ $20 \mathrm{~kg} \cdot \mathrm{S} \cdot \mathrm{ha}^{-1}+80 \mathrm{~kg} \cdot \mathrm{N} \cdot \mathrm{ha}^{-1}+20 \mathrm{~kg} \cdot \mathrm{P} \cdot \mathrm{ha}^{-1}$ & 80 & 20 & 0 & 20 \\
\hline 19 & Glycerol @ $1 \mathrm{Mg} \cdot \mathrm{ha}^{-1}+80 \mathrm{~kg} \cdot \mathrm{N} \cdot \mathrm{ha}^{-1}$ & 80 & ND & ND & ND \\
\hline 20 & Wood ash - fine @ $2 \mathrm{Mg} \cdot \mathrm{ha}^{-1}+80 \mathrm{~kg} \cdot \mathrm{N} \cdot \mathrm{ha}^{-1}$ & 80 & 10 & 90 & 26 \\
\hline 29 & Wood ash - granular @ $200 \mathrm{~kg} \cdot \mathrm{ha}^{-1}$ (applied side band) $+80 \mathrm{~kg} \cdot \mathrm{N} \cdot \mathrm{ha}^{-1}$ & 80 & 1 & 9 & 3 \\
\hline 11 & Triple superphosphate @ $20 \mathrm{~kg} \cdot \mathrm{P} \cdot \mathrm{ha}^{-1}+80 \mathrm{~kg} \cdot \mathrm{N} \cdot \mathrm{ha}^{-1}+20 \mathrm{~kg} \cdot \mathrm{S} \cdot \mathrm{ha}^{-1}$ & 80 & 20 & 0 & 20 \\
\hline 31 & $\mathrm{~N}$ only $-80 \mathrm{~kg} \cdot \mathrm{N} \cdot \mathrm{ha}^{-1}$ (using $34-0-0$ ) & 80 & 0 & 0 & 0 \\
\hline 30 & $\mathrm{~N}+\mathrm{P}-80 \mathrm{~kg} \cdot \mathrm{N} \cdot \mathrm{ha}^{-1}$ (using $\left.34-0-0\right)+20 \mathrm{~kg} \cdot \mathrm{P} \cdot \mathrm{ha}^{-1}$ (using $0-45-0$ ) & 80 & 20 & 0 & 0 \\
\hline 27 & $\mathrm{~N}+\mathrm{S}-80 \mathrm{~kg} \cdot \mathrm{N} \cdot \mathrm{ha}^{-1}$ (using $\left.34-0-0\right)+20 \mathrm{~kg} \cdot \mathrm{S} \cdot \mathrm{ha}^{-1}$ (using $0-0-51-17$ ) & 80 & 0 & 0 & 20 \\
\hline 12 & Penicillium bilaiae $+80 \mathrm{~kg} \cdot \mathrm{N} \cdot \mathrm{ha}^{-1}+20 \mathrm{~kg} \cdot \mathrm{S} \cdot \mathrm{ha}^{-1}$ & 80 & 0 & 0 & 20 \\
\hline 13 & $\begin{array}{l}\text { Rock phosphate granular (International Compost) @ } 20 \mathrm{~kg} \cdot \mathrm{P} \cdot \mathrm{ha}^{-1}+80 \mathrm{~kg} \cdot \mathrm{N} \cdot \mathrm{ha}^{-1}+20 \\
\mathrm{~kg} \cdot \mathrm{S} \cdot \mathrm{ha}^{-1}\end{array}$ & 80 & 20 & 0 & 20 \\
\hline 14 & $\begin{array}{l}\text { Rock phosphate finely-ground (International Compost) @ } 20 \mathrm{~kg} \cdot \mathrm{P} \cdot \mathrm{ha}^{-1}+80 \mathrm{~kg} \cdot \mathrm{N} \cdot \mathrm{ha}^{-1}+ \\
20 \mathrm{~kg} \cdot \mathrm{S} \cdot \mathrm{ha}^{-1}\end{array}$ & 80 & 20 & 0 & 20 \\
\hline 15 & Rock phosphate granular (BC Mines)@20 kg $\cdot \mathrm{P} \cdot \mathrm{ha}^{-1}+80 \mathrm{~kg} \cdot \mathrm{N} \cdot \mathrm{ha}^{-1}+20 \mathrm{~kg} \cdot \mathrm{S} \cdot \mathrm{ha}^{-1}$ & 80 & 20 & 0 & 20 \\
\hline 16 & Rock phosphate finely-ground (BC Mines) @ $20 \mathrm{~kg} \cdot \mathrm{P} \cdot \mathrm{ha}^{-1}+80 \mathrm{~kg} \cdot \mathrm{N} \cdot \mathrm{ha}^{-1}+20 \mathrm{~kg} \cdot \mathrm{S} \cdot \mathrm{ha}^{-1}$ & 80 & 20 & 0 & 20 \\
\hline 22 & $\begin{array}{l}\text { Rock phosphate granular (BC Mines) @ } 20 \mathrm{~kg} \cdot \mathrm{P} \cdot \mathrm{ha}^{-1}+80 \mathrm{~kg} \cdot \mathrm{N} \cdot \mathrm{ha}^{-1}+20 \mathrm{~kg} \cdot \mathrm{S} \cdot \mathrm{ha}^{-1}+ \\
\text { Penicillium bilaiae }\end{array}$ & 80 & 20 & 0 & 20 \\
\hline 23 & $\begin{array}{l}\text { Rock phosphate finely-ground (BC Mines) @ } 20 \mathrm{~kg} \cdot \mathrm{P} \cdot \mathrm{ha}^{-1}+80 \mathrm{~kg} \cdot \mathrm{N} \cdot \mathrm{ha}^{-1}+20 \mathrm{~kg} \cdot \mathrm{S} \cdot \mathrm{ha}^{-1} \\
+ \text { Penicillium bilaiae }\end{array}$ & 80 & 20 & 0 & 20 \\
\hline 24 & $\begin{array}{l}\text { Rock phosphate + humates granular (BC Mines) @ } 20 \mathrm{~kg} \cdot \mathrm{P} \cdot \mathrm{ha}^{-1}+80 \mathrm{~kg} \cdot \mathrm{N} \cdot \mathrm{ha}^{-1}+20 \\
\mathrm{~kg} \cdot \mathrm{S} \cdot \mathrm{ha}^{-1}\end{array}$ & 80 & 20 & 0 & 20 \\
\hline 25 & $\begin{array}{l}\text { Rock phosphate + humates granular (BC Mines) @ } 20 \mathrm{~kg} \cdot \mathrm{P} \cdot \mathrm{ha}^{-1}+80 \mathrm{~kg} \cdot \mathrm{N} \cdot \mathrm{ha}^{-1}+20 \\
\mathrm{~kg} \cdot \mathrm{S} \cdot \mathrm{ha}^{-1}+\text { Penicillium bilaiae }\end{array}$ & 80 & 20 & 0 & 20 \\
\hline 26 & Rock phosphate [powder] (BC Mines) @ $20 \mathrm{~kg} \cdot \mathrm{P} \cdot \mathrm{ha}^{-1}+80 \mathrm{~kg} \cdot \mathrm{N} \cdot \mathrm{ha}^{-1}+20 \mathrm{~kg} \cdot \mathrm{S} \cdot \mathrm{ha}^{-1}$ & 80 & 20 & 0 & 20 \\
\hline
\end{tabular}

"ND refers to nutrient analysis was not determined in glycerol, because it was expected to contain very little available nutrients, if any.

and August.

\subsection{Seed and Straw Yield}

Combined application of N, P and S chemical fertilizers (NPS) produced considerably greater seed yield of canola compared to the unamended control in all four years (Table 4). In treatments with only organic amendments, thin stillage produced the highest seed yield in all years, and it was similar (or even slightly greater in some years) to the NPS balanced fertilization treatment. Compared to the control, fish food additive and distiller grain dry of wheat in 2009, 2011 and 2012, distiller grain dry of corn in 2009 and 2012, compost in 2011, and alfalfa pellets in 2011 and 2012 produced significantly greater seed yield. There was also a moderate increase in seed yield with compost and alfalfa pellets in 2009 , alfalfa + 
Table 4. Seed yield of canola with various amendments applied annually in 2009, 2010, 2011 and 2012 at Star City, Saskatchewan.

\begin{tabular}{|c|c|c|c|c|c|}
\hline \multirow{2}{*}{\multicolumn{2}{|c|}{$\begin{array}{l}\text { Treatment } \\
\text { Amendments }\end{array}$}} & \multicolumn{4}{|c|}{ Seed yield $\left(\mathrm{kg} \cdot \mathrm{ha}^{-1}\right)$} \\
\hline & & 2009 & 2010 & 2011 & 2012 \\
\hline 1 & Control (no amendment) & 809 & 463 & 410 & 1099 \\
\hline 2 & Compost@20 Mg·ha ${ }^{-1}$ & 997 & 534 & 651 & 1118 \\
\hline 3 & Wood ash - fine @ $2 \mathrm{Mg} \cdot \mathrm{ha}^{-1}$ & 985 & 453 & 493 & 1297 \\
\hline 28 & Wood ash - granular @ $200 \mathrm{~kg} \cdot \mathrm{ha}^{-1}$ (applied side band) & 887 & 362 & 481 & 1000 \\
\hline 4 & Alfalfa pellets @ $2 \mathrm{Mg} \cdot \mathrm{ha}^{-1}$ & 985 & 563 & 628 & 1467 \\
\hline 5 & Alfalfa + canola meal pellets@ $2 \mathrm{Mg} \cdot \mathrm{ha}^{-1}$ & 1029 & 458 & 567 & 1369 \\
\hline 6 & Distiller grain (wheat) - wet @ $2 \mathrm{Mg} \cdot \mathrm{ha}^{-1}$ & 831 & 396 & 611 & 1249 \\
\hline 7 & Distiller grain (wheat) - dry @ $1 \mathrm{Mg} \cdot \mathrm{ha}^{-1}$ & 1422 & 541 & 989 & 1909 \\
\hline 21 & Distiller grain (corn) - dry @ $1 \mathrm{Mg} \cdot \mathrm{ha}^{-1}$ & 1340 & 396 & 614 & 1505 \\
\hline 8 & Thin stillage@ $20,000 \mathrm{~L} \cdot \mathrm{ha}^{-1}$ & 1976 & 853 & 1088 & 2264 \\
\hline 9 & Glycerol@ $1 \mathrm{Mg} \cdot \mathrm{ha}^{-1}$ & 663 & 512 & 321 & 1118 \\
\hline 10 & Fish food additive@ $1 \mathrm{Mg} \cdot \mathrm{ha}^{-1}$ & 1451 & 541 & 832 & 1763 \\
\hline 17 & Gypsum@ $20 \mathrm{~kg} \cdot \mathrm{S} \cdot \mathrm{ha}^{-1}+80 \mathrm{~kg} \cdot \mathrm{N} \cdot \mathrm{ha}^{-1}+20 \mathrm{~kg} \cdot \mathrm{P} \cdot \mathrm{ha}^{-1}$ & 1965 & 714 & 1184 & 2292 \\
\hline 18 & Rapid release elemental S@ $20 \mathrm{~kg} \cdot \mathrm{S} \cdot \mathrm{ha}^{-1}+80 \mathrm{~kg} \cdot \mathrm{N} \cdot \mathrm{ha}^{-1}+20 \mathrm{~kg} \cdot \mathrm{P} \cdot \mathrm{ha}^{-1}$ & 1960 & 615 & 1187 & 2231 \\
\hline 19 & Glycerol @ $1 \mathrm{Mg} \cdot \mathrm{ha}^{-1}+80 \mathrm{~kg} \cdot \mathrm{N} \cdot \mathrm{ha}^{-1}$ & 1559 & 308 & 497 & 1604 \\
\hline 20 & Wood ash - fine@ $2 \mathrm{Mg} \cdot \mathrm{ha}^{-1}+80 \mathrm{~kg} \cdot \mathrm{N} \cdot \mathrm{ha}^{-1}$ & 2015 & 834 & 1250 & 2254 \\
\hline 29 & Wood ash - granular @ $200 \mathrm{~kg} \cdot \mathrm{ha}^{-1}$ (applied side band) $+80 \mathrm{~kg} \cdot \mathrm{N} \cdot \mathrm{ha}^{-1}$ & 1869 & 563 & 814 & 2213 \\
\hline 11 & Triple superphosphate @ $20 \mathrm{~kg} \cdot \mathrm{P} \cdot \mathrm{ha}^{-1}+80 \mathrm{~kg} \cdot \mathrm{N} \cdot \mathrm{ha}^{-1}+20 \mathrm{~kg} \cdot \mathrm{S} \cdot \mathrm{ha}^{-1}$ & 1842 & 835 & 1262 & 2301 \\
\hline 31 & $\mathrm{~N}$ only $-80 \mathrm{~kg} \cdot \mathrm{N} \cdot \mathrm{ha}^{-1}$ (using $34-0-0$ ) & $\mathrm{ND}^{\mathrm{z}}$ & 230 & 247 & 989 \\
\hline 30 & $\mathrm{~N}+\mathrm{P}-80 \mathrm{~kg} \cdot \mathrm{N} \cdot \mathrm{ha}^{-1}$ (using $\left.34-0-0\right)+20 \mathrm{~kg} \cdot \mathrm{P} \cdot \mathrm{ha}^{-1}$ (using $0-45-0$ ) & ND & 491 & 854 & 1753 \\
\hline 27 & $\mathrm{~N}+\mathrm{S}-80 \mathrm{~kg} \cdot \mathrm{N} \cdot \mathrm{ha}^{-1}$ (using $\left.34-0-0\right)+20 \mathrm{~kg} \cdot \mathrm{S} \cdot \mathrm{ha}^{-1}$ (using $0-0-51-17$ ) & ND & 680 & 1083 & 2367 \\
\hline 12 & Penicillium bilaiae $+80 \mathrm{~kg} \cdot \mathrm{N} \cdot \mathrm{ha}^{-1}+20 \mathrm{~kg} \cdot \mathrm{S} \cdot \mathrm{ha}^{-1}$ & 1808 & 616 & 986 & 2170 \\
\hline 13 & $\begin{array}{l}\text { Rock phosphate granular (International Compost) @ } 20 \mathrm{~kg} \cdot \mathrm{P} \cdot \mathrm{ha}^{-1}+80 \mathrm{~kg} \cdot \mathrm{N} \cdot \mathrm{ha}^{-1}+20 \\
\mathrm{~kg} \cdot \mathrm{S} \cdot \mathrm{ha}^{-1}\end{array}$ & 1769 & 652 & 984 & 2146 \\
\hline 14 & $\begin{array}{l}\text { Rock phosphate finely-ground (International Compost) @ } 20 \mathrm{~kg} \cdot \mathrm{P} \cdot \mathrm{ha}^{-1}+80 \mathrm{~kg} \cdot \mathrm{N} \cdot \mathrm{ha}^{-1}+ \\
20 \mathrm{~kg} \cdot \mathrm{S} \cdot \mathrm{ha}^{-1}\end{array}$ & 1806 & 711 & 1196 & 2268 \\
\hline 15 & Rock phosphate granular (BC Mines) @ $20 \mathrm{~kg} \cdot \mathrm{P} \cdot \mathrm{ha}^{-1}+80 \mathrm{~kg} \cdot \mathrm{N} \cdot \mathrm{ha}^{-1}+20 \mathrm{~kg} \cdot \mathrm{S} \cdot \mathrm{ha}^{-1}$ & 1842 & 638 & 1010 & 2165 \\
\hline 16 & Rock phosphate finely-ground (BC Mines) @ $20 \mathrm{~kg} \cdot \mathrm{P} \cdot \mathrm{ha}^{-1}+80 \mathrm{~kg} \cdot \mathrm{N} \cdot \mathrm{ha}^{-1}+20 \mathrm{~kg} \cdot \mathrm{S} \cdot \mathrm{ha}^{-1}$ & 1843 & 698 & 1247 & 2219 \\
\hline 22 & $\begin{array}{l}\text { Rock phosphate granular (BC Mines) @ } 20 \mathrm{~kg} \cdot \mathrm{P} \cdot \mathrm{ha}^{-1}+80 \mathrm{~kg} \cdot \mathrm{N} \cdot \mathrm{ha}^{-1}+20 \mathrm{~kg} \cdot \mathrm{S} \cdot \mathrm{ha}^{-1}+ \\
\text { Penicillium bilaiae }\end{array}$ & 1987 & 568 & 974 & 2213 \\
\hline 23 & $\begin{array}{l}\text { Rock phosphate finely-ground (BC Mines) @ } 20 \mathrm{~kg} \cdot \mathrm{P} \cdot \mathrm{ha}^{-1}+80 \mathrm{~kg} \cdot \mathrm{N} \cdot \mathrm{ha}^{-1}+20 \mathrm{~kg} \cdot \mathrm{S} \cdot \mathrm{ha}^{-1} \\
+ \text { Penicillium bilaiae }\end{array}$ & 2034 & 702 & 1218 & 2434 \\
\hline 24 & $\begin{array}{l}\text { Rock phosphate + humates granular (BC Mines) @ } 20 \mathrm{~kg} \cdot \mathrm{P} \cdot \mathrm{ha}^{-1}+80 \mathrm{~kg} \cdot \mathrm{N} \cdot \mathrm{ha}^{-1}+20 \\
\mathrm{~kg} \cdot \mathrm{S} \cdot \mathrm{ha}^{-1}\end{array}$ & 1869 & 552 & 1126 & ND \\
\hline 25 & $\begin{array}{l}\text { Rock phosphate + humates granular (BC Mines) @ } 20 \mathrm{~kg} \cdot \mathrm{P} \cdot \mathrm{ha}^{-1}+80 \mathrm{~kg} \cdot \mathrm{N} \cdot \mathrm{ha}^{-1}+20 \\
\mathrm{~kg} \cdot \mathrm{S} \cdot \mathrm{ha}^{-1}+\text { Penicillium bilaiae }\end{array}$ & 2055 & 667 & 1045 & ND \\
\hline \multirow[t]{3}{*}{26} & Rock phosphate [powder] (BC Mines) @ $20 \mathrm{~kg} \cdot \mathrm{P} \cdot \mathrm{ha}^{-1}+80 \mathrm{~kg} \cdot \mathrm{N} \cdot \mathrm{ha}^{-1}+20 \mathrm{~kg} \cdot \mathrm{S} \cdot \mathrm{ha}^{-1}$ & 1850 & 689 & 1310 & 2233 \\
\hline & $\mathrm{LSD}_{0.05}$ & 250 & 193 & 207 & 361 \\
\hline & SEM $^{\mathrm{y}}$ & $88.7^{* * *}$ & $68.5^{* * *}$ & $73.6^{* * *}$ & $128.3^{* * *}$ \\
\hline
\end{tabular}

${ }^{\mathrm{z}} \mathrm{ND}$ refers to not determined; ${ }^{\mathrm{y},{ }^{* * *}}$ refers to significant treatment effects in ANOVA at $\mathrm{P} \leq 0.001$.

canola meal pellets in 2009, 2011 and 2012, with wood ash fine in 2009 and 2012, with distiller grain wet of wheat in 2011 and 2012, and distiller grain dry of corn in 2011, although not significant. This suggests the potential of these treatments possibly with long term repeated annual applications. There was a slight reduction in seed yield of canola from wood ash granular, glycerol, distiller grain wet of wheat and distiller grain dry of corn in a few years.

In treatments where chemical fertilizers were also applied in addition to organic amendments, application of $\mathrm{N}$ fertilizer increased seed yield substantially in wood 
ash fine treatment in all years. This suggests that wood ash fine was lacking in $\mathrm{N}$, and its application along with $\mathrm{N}$ fertilizer supplied the nutrients lacking in this soil (mainly S, and also possibly P to some extent). Application of $\mathrm{N}$ fertilizer also increased seed yield in wood ash granular treatment but mainly in 2009, 2011 and 2012, and to a lesser extent than wood ash fine. The poorer performance of wood ash granular than wood ash fine was most likely due to poor availability and/or possibly unequal distribution of nutrients to canola plants from sparse application of wood ash granules in relation to canola plants/roots. There was no beneficial effect of glycerol on seed yield, and application of $\mathrm{N}$ increased seed yield in glycerol treatment but only in 2009 and 2012 and seed yield was usually much less than gypsum $+\mathrm{N}+\mathrm{P}$ or NPS fertilizer treatment, suggesting the lack of $\mathrm{N}, \mathrm{S}$, and/or $\mathrm{P}$ in this treatment for optimum crop growth.

Compared to the unamended control, there was a considerable reduction in canola seed yield in 2010 and 2011, and a slight/moderate reduction in 2012, when only $\mathrm{N}$ fertilizer was applied without any sulphate-S. Application of $\mathrm{P}$ along with $\mathrm{N}(\mathrm{NP})$ resulted in some increase in seed yield compared to the $\mathrm{N}$ alone treatment, butnot significantly better than the control. The combined application of $\mathrm{N}$ (as ammonium nitrate) $+\mathrm{P}$ (as triple super phosphate) $+\mathrm{S}$ (potassium sulphate) chemical fertilizers (NPS) produced considerably higher seed yield of canola compared to the control. This suggests that seed yield of canola can be improved significantly by using balanced NPS fertilization/nutrition on this soil, extremely deficient in plant-available $\mathrm{N}$ and $\mathrm{S}$, and possibly containing insufficient amount of available $\mathrm{P}$ for optimum yield, especially with canola being a particular S-sensitive crop. Application of rapid release elemental S (RRES), along with $\mathrm{N}+\mathrm{P}$ fertilizer, usually produced seed yield similar to gypsum $+\mathrm{N}+\mathrm{P}$ treatment. Seed yields with both gypsum and RRES treatments were significantly greater than with the $\mathrm{N}$ only treatment, but slightly less than with the NPS treatment in some years.

Application of $\mathrm{N}+\mathrm{S}$, in combination with finelyground or powder rock phosphate, produced seed yield greater than that with granular rock phosphate, and it was similar to or only slightly lower than the NPS treatment, but only in 2011. This suggests the positive contribution of finely-ground or powder rock phosphate in increasing availability of $\mathrm{P}$ and improving seed yield of canola in the third growing season. The lower seed yield obtained with granular rock phosphate and/or Penicillium bilaiae, in combination with $\mathrm{N}+\mathrm{S}$, than the NPS treatment in all years suggests the poor performance of granular rock phosphate and/or Penicillium bilaiae in increasing $\mathrm{P}$ availability and improving seed yield of canola. The response trends of straw yield to all organic and inorganic amendments were generally similar to seed yield in most cases, with only a few exceptions (Table 5). For example, unlike seed yields, the straw yields were similar between NP and NPS treatments in 2011, and also there was some increase in straw yield with only $\mathrm{N}$ treatment compared to no amendment control in 2012.

\subsection{Protein and Oil Concentration in Seed}

Treatments including only organic amendments (i.e., without any chemical fertilizers) usually resulted in little or no significant effects on protein concentration in canola seed, although protein concentrations were increased or decreased in a few cases compared to the no amendment control treatment (Table 6). For example, there was an increase in protein concentration with thin stillage, fish food additive or distiller grain in 2011 or 2012 , and a reduction in protein concentration in canola seed using compost and wood ash treatments in 2010 and 2011. In treatments where chemical fertilizers were also applied, in addition to amendments, protein concentration in canola seed increased or tended to increase with glycerol, gypsum, RRES or wood ash treatments in some years. There was no beneficial effect of any amendment + chemical fertilizer treatment on oil concentration in canola seed, but there was a tendency of decrease in oil concentration in canola seed in the $\mathrm{N}$, glycerol $+\mathrm{N}$ and NP treatments in 2010, 2011 and 2012, and in the NS or NPS treatment in 2011 (Table 7).

\subsection{Nutrient Uptake in Seed + Straw}

The response trends of uptake of total N, P, K and S in seed and straw to organic and inorganic amendments were generally similar to the corresponding seed and straw yields, respectively (data not shown). The results on uptake of total N, P, K and S in seed + straw of canola are presented in Tables 8-11. In treatments with only organic amendments, total $\mathrm{N}$ uptake in seed + straw with thin stillage was similar (or even slightly higher in some cases) to the NPS balanced fertilization treatment (Table 8). Compared to the control, fish food additive in all four years, distiller grain dry of wheat in 2009, 2011 and 2012, distiller grain dry of corn in 2009 and 2012, and alfalfa pellets in 2012 produced significantly greater total $\mathrm{N}$ uptake in seed + straw. There was also a moderate increase in total $\mathrm{N}$ uptake in seed + straw with compost and alfalfa pellets in 2009 and 2011, alfalfa + canola meal pellets in 2009, 2011 and 2012, with wood ash fine in 2009 and 2012, with distiller grain wet of wheat in 2011 and 2012, and distiller grain dry of corn in 2011, although not significant. There was a slight reduction in total $\mathrm{N}$ uptake in seed + strawof canola from wood ash granular, glycerol, distiller grain wet of wheat and distiller grain dry of corn in a few years. 
Table 5. Straw yield of canola with various amendments applied annually in 2009, 2010, 2011 and 2012 at Star City, Saskatchewan.

\begin{tabular}{|c|c|c|c|c|c|}
\hline \multirow{2}{*}{\multicolumn{2}{|c|}{$\begin{array}{l}\text { Treatment } \\
\text { Amendments }\end{array}$}} & \multicolumn{4}{|c|}{ Straw yield $\left(\mathrm{kg} \cdot \mathrm{ha}^{-1}\right)$} \\
\hline & & 2009 & 2010 & 2011 & 2012 \\
\hline 1 & Control (no amendment) & 2579 & 1781 & 2545 & 2864 \\
\hline 2 & Compost@20 Mg·ha ${ }^{-1}$ & 3284 & 1766 & 2781 & 2604 \\
\hline 3 & Wood ash - fine@ $2 \mathrm{Mg} \cdot \mathrm{ha}^{-1}$ & 3169 & 1817 & 2363 & 2894 \\
\hline 28 & Wood ash - granular@ $200 \mathrm{~kg} \cdot \mathrm{ha}^{-1}$ (applied side band) & 2689 & 1500 & 2201 & 2356 \\
\hline 4 & Alfalfa pellets@ $2 \mathrm{Mg} \cdot \mathrm{ha}^{-1}$ & 3118 & 2330 & 2810 & 3594 \\
\hline 5 & Alfalfa + canola meal pellets@2 Mg $\cdot \mathrm{ha}^{-1}$ & 3285 & 1697 & 2689 & 2916 \\
\hline 6 & Distiller grain (wheat) - wet @ $2 \mathrm{Mg} \cdot \mathrm{ha}^{-1}$ & 2705 & 1365 & 2858 & 2831 \\
\hline 7 & Distiller grain (wheat) - dry @ $1 \mathrm{Mg} \cdot \mathrm{ha}^{-1}$ & 4462 & 2001 & 3118 & 3675 \\
\hline 21 & Distiller grain (corn) - dry @1 Mg ha ${ }^{-1}$ & 3817 & 1756 & 2621 & 2998 \\
\hline 8 & Thin stillage @ 20,000 L·ha ${ }^{-1}$ & 5477 & 3004 & 3301 & 3917 \\
\hline 9 & Glycerol@1 Mg ha ${ }^{-1}$ & 2130 & 1726 & 1776 & 2500 \\
\hline 10 & Fish food additive@ $1 \mathrm{Mg} \cdot \mathrm{ha}^{-1}$ & 4753 & 2553 & 3247 & 3470 \\
\hline 17 & Gypsum@20 kg $\cdot \mathrm{S} \cdot \mathrm{ha}^{-1}+80 \mathrm{~kg} \cdot \mathrm{N} \cdot \mathrm{ha}^{-1}+20 \mathrm{~kg} \cdot \mathrm{P} \cdot \mathrm{ha}^{-1}$ & 5461 & 2912 & 3961 & 4198 \\
\hline 18 & Rapid release elemental S @ $20 \mathrm{~kg} \cdot \mathrm{S} \cdot \mathrm{ha}^{-1}+80 \mathrm{~kg} \cdot \mathrm{N} \cdot \mathrm{ha}^{-1}+20 \mathrm{~kg} \cdot \mathrm{P} \cdot \mathrm{ha}^{-1}$ & 5910 & 2427 & 4537 & 3768 \\
\hline 19 & Glycerol @ $1 \mathrm{Mg} \cdot \mathrm{ha}^{-1}+80 \mathrm{~kg} \cdot \mathrm{N} \cdot \mathrm{ha}^{-1}$ & 4388 & 1175 & 2624 & 3840 \\
\hline 20 & Wood ash - fine @2 Mg ha ${ }^{-1}+80 \mathrm{~kg} \cdot \mathrm{N} \cdot \mathrm{ha}^{-1}$ & 5376 & 3753 & 4090 & 4241 \\
\hline 29 & Wood ash - granular@ $200 \mathrm{~kg} \cdot \mathrm{ha}^{-1}$ (applied side band) $+80 \mathrm{~kg} \cdot \mathrm{N} \cdot \mathrm{ha}^{-1}$ & 5384 & 2051 & 4114 & 4327 \\
\hline 11 & Triple superphosphate @ $20 \mathrm{~kg} \cdot \mathrm{P} \cdot \mathrm{ha}^{-1}+80 \mathrm{~kg} \cdot \mathrm{N} \cdot \mathrm{ha}^{-1}+20 \mathrm{~kg} \cdot \mathrm{S} \cdot \mathrm{ha}^{-1}$ & 5972 & 3206 & 4154 & 4568 \\
\hline 31 & $\mathrm{~N}$ only $-80 \mathrm{~kg} \cdot \mathrm{N} \cdot \mathrm{ha}^{-1}$ (using $34-0-0$ ) & $\mathrm{ND}^{\mathrm{z}}$ & 1112 & 1937 & 3546 \\
\hline 30 & $\mathrm{~N}+\mathrm{P}-80 \mathrm{~kg} \cdot \mathrm{N} \cdot \mathrm{ha}^{-1}$ (using $\left.34-0-0\right)+20 \mathrm{~kg} \cdot \mathrm{P} \cdot \mathrm{ha}^{-1}$ (using $0-45-0$ ) & ND & 2007 & 4516 & 3875 \\
\hline 27 & $\mathrm{~N}+\mathrm{S}-80 \mathrm{~kg} \cdot \mathrm{N} \cdot \mathrm{ha}^{-1}$ (using $\left.34-0-0\right)+20 \mathrm{~kg} \cdot \mathrm{S} \cdot \mathrm{ha}^{-1}$ (using $0-0-51-17$ ) & ND & 2489 & 4088 & 3815 \\
\hline 12 & Penicillium bilaiae $+80 \mathrm{~kg} \cdot \mathrm{N} \cdot \mathrm{ha}^{-1}+20 \mathrm{~kg} \cdot \mathrm{S} \cdot \mathrm{ha}^{-1}$ & 4895 & 2992 & 3896 & 4114 \\
\hline 13 & $\begin{array}{l}\text { Rock phosphate granular (International Compost) @ } 20 \mathrm{~kg} \cdot \mathrm{P} \cdot \mathrm{ha}^{-1}+80 \mathrm{~kg} \cdot \mathrm{N} \cdot \mathrm{ha}^{-1}+20 \\
\mathrm{~kg} \cdot \mathrm{S} \cdot \mathrm{ha}^{-1}\end{array}$ & 5323 & 2212 & 3716 & 4367 \\
\hline 14 & $\begin{array}{l}\text { Rock phosphate finely-ground (International Compost) @ } 20 \mathrm{~kg} \cdot \mathrm{P} \cdot \mathrm{ha}^{-1}+80 \mathrm{~kg} \cdot \mathrm{N} \cdot \mathrm{ha}^{-1}+ \\
20 \mathrm{~kg} \cdot \mathrm{S} \cdot \mathrm{ha}^{-1}\end{array}$ & 5564 & 2521 & 3751 & 4614 \\
\hline 15 & Rock phosphate granular (BC Mines) @ $20 \mathrm{~kg} \cdot \mathrm{P} \cdot \mathrm{ha}^{-1}+80 \mathrm{~kg} \cdot \mathrm{N} \cdot \mathrm{ha}^{-1}+20 \mathrm{~kg} \cdot \mathrm{S} \cdot \mathrm{ha}^{-1}$ & 5333 & 2645 & 3783 & 3984 \\
\hline 16 & Rock phosphate finely-ground (BC Mines) @ $20 \mathrm{~kg} \cdot \mathrm{P} \cdot \mathrm{ha}^{-1}+80 \mathrm{~kg} \cdot \mathrm{N} \cdot \mathrm{ha}^{-1}+20 \mathrm{~kg} \cdot \mathrm{S} \cdot \mathrm{ha}^{-1}$ & 5168 & 2699 & 4381 & 4144 \\
\hline 22 & $\begin{array}{l}\text { Rock phosphate granular (BC Mines) @ } 20 \mathrm{~kg} \cdot \mathrm{P} \cdot \mathrm{ha}^{-1}+80 \mathrm{~kg} \cdot \mathrm{N} \cdot \mathrm{ha}^{-1}+20 \mathrm{~kg} \cdot \mathrm{S} \cdot \mathrm{ha}^{-1}+ \\
\text { Penicillium bilaiae }\end{array}$ & 5082 & 2415 & 3513 & 4078 \\
\hline 23 & $\begin{array}{l}\text { Rock phosphate finely-ground (BC Mines) @ } 20 \mathrm{~kg} \cdot \mathrm{P} \cdot \mathrm{ha}^{-1}+80 \mathrm{~kg} \cdot \mathrm{N} \cdot \mathrm{ha}^{-1}+20 \mathrm{~kg} \cdot \mathrm{S} \cdot \mathrm{ha}^{-1} \\
+ \text { Penicillium bilaiae }\end{array}$ & 5767 & 2441 & 3996 & 4176 \\
\hline 24 & $\begin{array}{l}\text { Rock phosphate + humates granular (BC Mines) @ } 20 \mathrm{~kg} \cdot \mathrm{P} \cdot \mathrm{ha}^{-1}+80 \mathrm{~kg} \cdot \mathrm{N} \cdot \mathrm{ha}^{-1}+20 \\
\mathrm{~kg} \cdot \mathrm{S} \cdot \mathrm{ha}^{-1}\end{array}$ & 5243 & 2260 & 3777 & ND \\
\hline 25 & $\begin{array}{l}\text { Rock phosphate + humates granular (BC Mines) @ } 20 \mathrm{~kg} \cdot \mathrm{P} \cdot \mathrm{ha}^{-1}+80 \mathrm{~kg} \cdot \mathrm{N} \cdot \mathrm{ha}^{-1}+20 \\
\mathrm{~kg} \cdot \mathrm{S} \cdot \mathrm{ha}^{-1}+\text { Penicillium bilaiae }\end{array}$ & 5876 & 2338 & 4414 & ND \\
\hline \multirow[t]{3}{*}{26} & Rock phosphate [powder] (BC Mines) @ $20 \mathrm{~kg} \cdot \mathrm{P} \cdot \mathrm{ha}^{-1}+80 \mathrm{~kg} \cdot \mathrm{N} \cdot \mathrm{ha}^{-1}+20 \mathrm{~kg} \cdot \mathrm{S} \cdot \mathrm{ha}^{-1}$ & 5491 & 2556 & 4837 & 3337 \\
\hline & $\mathrm{LSD}_{0.05}$ & 860 & 908 & 1009 & 1006 \\
\hline & SEM $^{\mathrm{y}}$ & $305.6^{* * *}$ & $323.2^{* * *}$ & $359.1^{* * *}$ & $357.8^{* * *}$ \\
\hline
\end{tabular}

${ }^{\mathrm{z}} \mathrm{ND}$ refers to not determined; ${ }^{\mathrm{y},{ }^{* *}}$ refers to significant treatment effects in ANOVA at $\mathrm{P} \leq 0.001$.

In treatments where chemical fertilizers were also applied, in addition to organic amendments, application of $\mathrm{N}$ fertilizer substantially increased total $\mathrm{N}$ uptake in seed + straw with wood ash fine treatment in all years. This indicates that wood ash fine was lacking in $\mathrm{N}$, and its application along with $\mathrm{N}$ fertilizer supplied the nutrients lacking in this soil (mainly $\mathrm{S}$, and also possibly $\mathrm{P}$ to some extent), resulting in increased $\mathrm{N}$ uptake. Application of $\mathrm{N}$ fertilizer also increased total $\mathrm{N}$ uptake in seed + straw with wood ash granular treatment but mainly in 2009, 2011 and 2012, but to a lesser extent than with wood ash fine. The poor performance of wood ash granular 
Table 6. Protein concentration in canola seed with various amendments applied annually in 2009, 2010, 2011 and 2012 at Star City, Saskatchewan.

\begin{tabular}{|c|c|c|c|c|c|}
\hline \multirow{2}{*}{\multicolumn{2}{|c|}{$\begin{array}{l}\text { Treatment } \\
\text { Amendments }\end{array}$}} & \multicolumn{4}{|c|}{ Protein concentration in seed $\left(\mathrm{g} \cdot \mathrm{kg}^{-1}\right)$} \\
\hline & & 2009 & 2010 & 2011 & 2012 \\
\hline 1 & Control (no amendment) & 206 & 233 & 228 & 234 \\
\hline 2 & Compost@20 Mg·ha ${ }^{-1}$ & 207 & 215 & 204 & 237 \\
\hline 3 & Wood ash-fine@2 Mg.ha ${ }^{-1}$ & 204 & 213 & 208 & 227 \\
\hline 28 & Wood ash - granular@ $200 \mathrm{~kg} \cdot \mathrm{ha}^{-1}$ (applied side band) & 209 & 221 & 215 & 238 \\
\hline 4 & Alfalfa pellets @ $2 \mathrm{Mg} \cdot \mathrm{ha}^{-1}$ & 204 & 227 & 231 & 241 \\
\hline 5 & Alfalfa + canola meal pellets @ $2 \mathrm{Mg} \cdot \mathrm{ha}^{-1}$ & 208 & 229 & 224 & 246 \\
\hline 6 & Distiller grain (wheat) - wet @ $2 \mathrm{Mg} \cdot \mathrm{ha}^{-1}$ & 203 & 232 & 239 & 248 \\
\hline 7 & Distiller grain (wheat)-dry @ $1 \mathrm{Mg} \cdot \mathrm{ha}^{-1}$ & 201 & 228 & 253 & 253 \\
\hline 21 & Distiller grain (corn) - dry @ $1 \mathrm{Mg} \cdot \mathrm{ha}^{-1}$ & 209 & 228 & 229 & 259 \\
\hline 8 & Thin stillage @ 20,000 L·ha ${ }^{-1}$ & 207 & 232 & 276 & 263 \\
\hline 9 & Glycerol@1 Mg ha ${ }^{-1}$ & 216 & 230 & 215 & 227 \\
\hline 10 & Fish food additive @ $1 \mathrm{Mg} \cdot \mathrm{ha}^{-1}$ & 199 & 241 & 266 & 254 \\
\hline 17 & Gypsum @ $20 \mathrm{~kg} \cdot \mathrm{S} \cdot \mathrm{ha}^{-1}+80 \mathrm{~kg} \cdot \mathrm{N} \cdot \mathrm{ha}^{-1}+20 \mathrm{~kg} \cdot \mathrm{P} \cdot \mathrm{ha}^{-1}$ & 213 & 221 & 267 & 248 \\
\hline 18 & Rapid release elemental S @ $20 \mathrm{~kg} \cdot \mathrm{S} \cdot \mathrm{ha}^{-1}+80 \mathrm{~kg} \cdot \mathrm{N} \cdot \mathrm{ha}^{-1}+20 \mathrm{~kg} \cdot \mathrm{P} \cdot \mathrm{ha}^{-1}$ & 215 & 234 & 271 & 252 \\
\hline 19 & Glycerol@ $1 \mathrm{Mg} \cdot \mathrm{ha}^{-1}+80 \mathrm{~kg} \cdot \mathrm{N} \cdot \mathrm{ha}^{-1}$ & 215 & 252 & 267 & 242 \\
\hline 20 & Wood ash - fine@ $2 \mathrm{Mg} \cdot \mathrm{ha}^{-1}+80 \mathrm{~kg} \cdot \mathrm{N} \cdot \mathrm{ha}^{-1}$ & 219 & 221 & 263 & 240 \\
\hline 29 & Wood ash - granular@ $200 \mathrm{~kg} \cdot \mathrm{ha}^{-1}$ (applied side band) $+80 \mathrm{~kg} \cdot \mathrm{N} \cdot \mathrm{ha}^{-1}$ & 222 & 238 & 279 & 243 \\
\hline 11 & Triple superphosphate @ $20 \mathrm{~kg} \cdot \mathrm{P} \cdot \mathrm{ha}^{-1}+80 \mathrm{~kg} \cdot \mathrm{N} \cdot \mathrm{ha}^{-1}+20 \mathrm{~kg} \cdot \mathrm{S} \cdot \mathrm{ha}^{-1}$ & 202 & 229 & 271 & 245 \\
\hline 31 & $\mathrm{~N}$ only $-80 \mathrm{~kg} \cdot \mathrm{N} \cdot \mathrm{ha}^{-1}$ (using $34-0-0$ ) & $\mathrm{ND}^{\mathrm{z}}$ & 244 & 267 & 250 \\
\hline 30 & $\mathrm{~N}+\mathrm{P}-80 \mathrm{~kg} \cdot \mathrm{N} \cdot \mathrm{ha}^{-1}$ (using $\left.34-0-0\right)+20 \mathrm{~kg} \cdot \mathrm{P} \cdot \mathrm{ha}^{-1}$ (using $0-45-0$ ) & ND & 244 & 279 & 252 \\
\hline 27 & $\mathrm{~N}+\mathrm{S}-80 \mathrm{~kg} \cdot \mathrm{N} \cdot \mathrm{ha}^{-1}$ (using $\left.34-0-0\right)+20 \mathrm{~kg} \cdot \mathrm{S} \cdot \mathrm{ha}^{-1}$ (using $0-0-51-17$ ) & ND & 238 & 283 & 251 \\
\hline 12 & Penicillium bilaiae $+80 \mathrm{~kg} \cdot \mathrm{N} \cdot \mathrm{ha}^{-1}+20 \mathrm{~kg} \cdot \mathrm{S} \cdot \mathrm{ha}^{-1}$ & 213 & 235 & 285 & 257 \\
\hline 13 & $\begin{array}{l}\text { Rock phosphate granular (International Compost) @ } 20 \mathrm{~kg} \cdot \mathrm{P} \cdot \mathrm{ha}^{-1}+80 \mathrm{~kg} \cdot \mathrm{N} \cdot \mathrm{ha}^{-1}+20 \\
\mathrm{~kg} \cdot \mathrm{S} \cdot \mathrm{ha}^{-1}\end{array}$ & 208 & 243 & 288 & 256 \\
\hline 14 & $\begin{array}{l}\text { Rock phosphate finely-ground (International Compost) @ } 20 \mathrm{~kg} \cdot \mathrm{P} \cdot \mathrm{ha}^{-1}+80 \mathrm{~kg} \cdot \mathrm{N} \cdot \mathrm{ha}^{-1}+ \\
20 \mathrm{~kg} \cdot \mathrm{S} \cdot \mathrm{ha}^{-1}\end{array}$ & 207 & 239 & 277 & 254 \\
\hline 15 & Rock phosphate granular (BC Mines) @ $20 \mathrm{~kg} \cdot \mathrm{P} \cdot \mathrm{ha}^{-1}+80 \mathrm{~kg} \cdot \mathrm{N} \cdot \mathrm{ha}^{-1}+20 \mathrm{~kg} \cdot \mathrm{S} \cdot \mathrm{ha}^{-1}$ & 208 & 234 & 284 & 253 \\
\hline 16 & Rock phosphate finely-ground (BC Mines) @ $20 \mathrm{~kg} \cdot \mathrm{P} \cdot \mathrm{ha}^{-1}+80 \mathrm{~kg} \cdot \mathrm{N} \cdot \mathrm{ha}^{-1}+20 \mathrm{~kg} \cdot \mathrm{S} \cdot \mathrm{ha}^{-1}$ & 209 & 233 & 262 & 251 \\
\hline 22 & $\begin{array}{l}\text { Rock phosphate granular (BC Mines) @ } 20 \mathrm{~kg} \cdot \mathrm{P} \cdot \mathrm{ha}^{-1}+80 \mathrm{~kg} \cdot \mathrm{N} \cdot \mathrm{ha}^{-1}+20 \mathrm{~kg} \cdot \mathrm{S} \cdot \mathrm{ha}^{-1}+ \\
\text { Penicillium bilaiae }\end{array}$ & 214 & 238 & 276 & 255 \\
\hline 23 & $\begin{array}{l}\text { Rock phosphate finely-ground (BC Mines) @ } 20 \mathrm{~kg} \cdot \mathrm{P} \cdot \mathrm{ha}^{-1}+80 \mathrm{~kg} \cdot \mathrm{N} \cdot \mathrm{ha}^{-1}+20 \mathrm{~kg} \cdot \mathrm{S} \cdot \mathrm{ha}{ }^{-1} \\
+ \text { Penicillium bilaiae }\end{array}$ & 215 & 228 & 279 & 247 \\
\hline 24 & $\begin{array}{l}\text { Rock phosphate + humates granular (BC Mines) @ } 20 \mathrm{~kg} \cdot \mathrm{P} \cdot \mathrm{ha}^{-1}+80 \mathrm{~kg} \cdot \mathrm{N} \cdot \mathrm{ha}^{-1}+20 \\
\mathrm{~kg} \cdot \mathrm{S} \cdot \mathrm{ha}^{-1}\end{array}$ & 209 & 233 & 281 & ND \\
\hline 25 & $\begin{array}{l}\text { Rock phosphate + humates granular (BC Mines) @ } 20 \mathrm{~kg} \cdot \mathrm{P} \cdot \mathrm{ha}^{-1}+80 \mathrm{~kg} \cdot \mathrm{N} \cdot \mathrm{ha}^{-1}+20 \\
\mathrm{~kg} \cdot \mathrm{S} \cdot \mathrm{ha}^{-1}+\text { Penicillium bilaiae }\end{array}$ & 209 & 238 & 287 & ND \\
\hline \multirow[t]{3}{*}{26} & Rock phosphate [powder] (BC Mines) @ $20 \mathrm{~kg} \cdot \mathrm{P} \cdot \mathrm{ha}^{-1}+80 \mathrm{~kg} \cdot \mathrm{N} \cdot \mathrm{ha}^{-1}+20 \mathrm{~kg} \cdot \mathrm{S} \cdot \mathrm{ha}^{-1}$ & 210 & 231 & 271 & 251 \\
\hline & $\operatorname{LSD}_{0.05}$ & 9.9 & 14 & 14 & 10 \\
\hline & SEM $^{\mathrm{y}}$ & $3.5^{* *}$ & $5.1^{* * *}$ & $4.9^{* * *}$ & $3.5^{* * *}$ \\
\hline
\end{tabular}

${ }^{\mathrm{z}} \mathrm{ND}$ refers to not determined; ${ }^{\mathrm{y},{ }^{* *}}$ and ${ }^{* * *}$ refer to significant treatment effects in ANOVA at $\mathrm{P} \leq 0.1$ and $\mathrm{P} \leq 0.001$, respectively.

compared to wood ash fine was most likely due to poor availability and/or possibly unequal distribution of nutrients to canola plants from sparse application of wood ash granules in relation to canola plants/roots. There was no beneficial effect of glycerol on total $\mathrm{N}$ uptake in seed
+ straw. Application of $\mathrm{N}$ fertilizer increased total $\mathrm{N}$ uptake in seed + straw with glycerol treatment only in 2009 and 2012, but total $\mathrm{N}$ uptake was usually much less than with gypsum $+\mathrm{N}+\mathrm{P}$ or NPS fertilizer treatment, suggesting the lack of $\mathrm{N}, \mathrm{S}$, and/or $\mathrm{P}$ in this treatment for 
Table 7. Oil concentration in canola seed with various amendments applied annually in 2009, 2010, 2011 and 2012 at Star City, Saskatchewan.

\begin{tabular}{|c|c|c|c|c|c|}
\hline \multirow{2}{*}{\multicolumn{2}{|c|}{$\begin{array}{l}\text { Treatment } \\
\text { Amendments }\end{array}$}} & \multicolumn{4}{|c|}{ Oil concentration in seed $\left(\mathrm{g} \cdot \mathrm{kg}^{-1}\right)$} \\
\hline & & 2009 & 2010 & 2011 & 2012 \\
\hline 1 & Control (no amendment) & 506 & 469 & 451 & 458 \\
\hline 2 & Compost@20 Mg $\cdot \mathrm{ha}^{-1}$ & 507 & 479 & 479 & 449 \\
\hline 3 & Wood ash - fine @2 Mg.ha ${ }^{-1}$ & 510 & 488 & 477 & 466 \\
\hline 28 & Wood ash - granular @ $200 \mathrm{~kg} \cdot \mathrm{ha}^{-1}$ (applied side band) & 507 & 475 & 468 & 452 \\
\hline 4 & Alfalfa pellets@ $2 \mathrm{Mg} \cdot \mathrm{ha}^{-1}$ & 509 & 470 & 444 & 457 \\
\hline 5 & Alfalfa + canola meal pellets@ $2 \mathrm{Mg} \cdot \mathrm{ha}^{-1}$ & 508 & 471 & 465 & 452 \\
\hline 6 & Distiller grain (wheat) - wet @ $2 \mathrm{Mg} \cdot \mathrm{ha}^{-1}$ & 511 & 470 & 455 & 448 \\
\hline 7 & Distiller grain (wheat) - dry @ $1 \mathrm{Mg} \cdot \mathrm{ha}^{-1}$ & 517 & 469 & 437 & 448 \\
\hline 21 & Distiller grain (corn) - dry @ $1 \mathrm{Mg} \cdot \mathrm{ha}^{-1}$ & 509 & 463 & 466 & 430 \\
\hline 8 & Thin stillage @20,000 L·ha ${ }^{-1}$ & 504 & 457 & 418 & 432 \\
\hline 9 & Glycerol@1 Mg $\cdot \mathrm{ha}^{-1}$ & 500 & 473 & 473 & 465 \\
\hline 10 & Fish food additive@ $1 \mathrm{Mg} \cdot \mathrm{ha}^{-1}$ & 511 & 444 & 421 & 445 \\
\hline 17 & Gypsum @ $20 \mathrm{~kg} \cdot \mathrm{S} \cdot \mathrm{ha}^{-1}+80 \mathrm{~kg} \cdot \mathrm{N} \cdot \mathrm{ha}^{-1}+20 \mathrm{~kg} \cdot \mathrm{P} \cdot \mathrm{ha}^{-1}$ & 493 & 470 & 422 & 450 \\
\hline 18 & Rapid release elemental S @ $20 \mathrm{~kg} \cdot \mathrm{S} \cdot \mathrm{ha}^{-1}+80 \mathrm{~kg} \cdot \mathrm{N} \cdot \mathrm{ha}^{-1}+20 \mathrm{~kg} \cdot \mathrm{P} \cdot \mathrm{ha}^{-1}$ & 491 & 458 & 414 & 449 \\
\hline 19 & Glycerol@ $1 \mathrm{Mg} \cdot \mathrm{ha}^{-1}+80 \mathrm{~kg} \cdot \mathrm{N} \cdot \mathrm{ha}^{-1}$ & 492 & 436 & 419 & 453 \\
\hline 20 & Wood ash - fine @ $2 \mathrm{Mg} \cdot \mathrm{ha}^{-1}+80 \mathrm{~kg} \cdot \mathrm{N} \cdot \mathrm{ha}^{-1}$ & 493 & 483 & 415 & 463 \\
\hline 29 & Wood ash - granular @ $200 \mathrm{~kg} \cdot \mathrm{ha}^{-1}$ (applied side band) $+80 \mathrm{~kg} \cdot \mathrm{N} \cdot \mathrm{ha}^{-1}$ & 487 & 457 & 385 & 459 \\
\hline 11 & Triple superphosphate @ $20 \mathrm{~kg} \cdot \mathrm{P} \cdot \mathrm{ha}^{-1}+80 \mathrm{~kg} \cdot \mathrm{N} \cdot \mathrm{ha}^{-1}+20 \mathrm{~kg} \cdot \mathrm{S} \cdot \mathrm{ha}^{-1}$ & 502 & 469 & 410 & 451 \\
\hline 31 & $\mathrm{~N}$ only $-80 \mathrm{~kg} \cdot \mathrm{N} \cdot \mathrm{ha}^{-1}$ (using $34-0-0$ ) & $\mathrm{ND}^{\mathrm{z}}$ & 428 & 387 & 415 \\
\hline 30 & $\mathrm{~N}+\mathrm{P}-80 \mathrm{~kg} \cdot \mathrm{N} \cdot \mathrm{ha}^{-1}$ (using $\left.34-0-0\right)+20 \mathrm{~kg} \cdot \mathrm{P} \cdot \mathrm{ha}^{-1}$ (using $0-45-0$ ) & ND & 439 & 383 & 437 \\
\hline 27 & $\mathrm{~N}+\mathrm{S}-80 \mathrm{~kg} \cdot \mathrm{N} \cdot \mathrm{ha}^{-1}$ (using $\left.34-0-0\right)+20 \mathrm{~kg} \cdot \mathrm{S} \cdot \mathrm{ha}^{-1}$ (using $0-0-51-17$ ) & ND & 461 & 404 & 453 \\
\hline 12 & Penicillium bilaiae $+80 \mathrm{~kg} \cdot \mathrm{N} \cdot \mathrm{ha}^{-1}+20 \mathrm{~kg} \cdot \mathrm{S} \cdot \mathrm{ha}^{-1}$ & 499 & 470 & 406 & 450 \\
\hline 13 & $\begin{array}{l}\text { Rock phosphate granular (International Compost) @ } 20 \mathrm{~kg} \cdot \mathrm{P} \cdot \mathrm{ha}^{-1}+80 \mathrm{~kg} \cdot \mathrm{N} \cdot \mathrm{ha}^{-1}+20 \\
\mathrm{~kg} \cdot \mathrm{S} \cdot \mathrm{ha}^{-1}\end{array}$ & 503 & 459 & 410 & 449 \\
\hline 14 & $\begin{array}{l}\text { Rock phosphate finely-ground (International Compost)@20 kg } \cdot \mathrm{P} \cdot \mathrm{ha}^{-1}+80 \mathrm{~kg} \cdot \mathrm{N} \cdot \mathrm{ha}^{-1}+ \\
20 \mathrm{~kg} \cdot \mathrm{S} \cdot \mathrm{ha}^{-1}\end{array}$ & 498 & 459 & 415 & 450 \\
\hline 15 & Rock phosphate granular(BC Mines)@20 kg $\cdot \mathrm{P} \cdot \mathrm{ha}^{-1}+80 \mathrm{~kg} \cdot \mathrm{N} \cdot \mathrm{ha}^{-1}+20 \mathrm{~kg} \cdot \mathrm{S} \cdot \mathrm{ha}^{-1}$ & 500 & 458 & 403 & 448 \\
\hline 16 & Rock phosphate finely-ground (BC Mines) @ $20 \mathrm{~kg} \cdot \mathrm{P} \cdot \mathrm{ha}^{-1}+80 \mathrm{~kg} \cdot \mathrm{N} \cdot \mathrm{ha}^{-1}+20 \mathrm{~kg} \cdot \mathrm{S} \cdot \mathrm{ha}^{-1}$ & 498 & 452 & 355 & 453 \\
\hline 22 & $\begin{array}{l}\text { Rock phosphate granular (BC Mines) @ } 20 \mathrm{~kg} \cdot \mathrm{P} \cdot \mathrm{ha}^{-1}+80 \mathrm{~kg} \cdot \mathrm{N} \cdot \mathrm{ha}^{-1}+20 \mathrm{~kg} \cdot \mathrm{S} \cdot \mathrm{ha}^{-1}+ \\
\text { Penicillium bilaiae }\end{array}$ & 497 & 462 & 392 & 455 \\
\hline 23 & $\begin{array}{l}\text { Rock phosphate finely-ground (BC Mines)@ } 20 \mathrm{~kg} \cdot \mathrm{P} \cdot \mathrm{ha}^{-1}+80 \mathrm{~kg} \cdot \mathrm{N} \cdot \mathrm{ha}^{-1}+20 \mathrm{~kg} \cdot \mathrm{S} \cdot \mathrm{ha}^{-1} \\
+ \text { Penicillium bilaiae }\end{array}$ & 495 & 481 & 413 & 457 \\
\hline 24 & $\begin{array}{l}\text { Rock phosphate + humates granular (BC Mines) @ } 20 \mathrm{~kg} \cdot \mathrm{P} \cdot \mathrm{ha}^{-1}+80 \mathrm{~kg} \cdot \mathrm{N} \cdot \mathrm{ha}^{-1}+20 \\
\mathrm{~kg} \cdot \mathrm{S} \cdot \mathrm{ha}^{-1}\end{array}$ & 500 & 470 & 408 & ND \\
\hline 25 & $\begin{array}{l}\text { Rock phosphate + humates granular (BC Mines) @ } 20 \mathrm{~kg} \cdot \mathrm{P} \cdot \mathrm{ha}^{-1}+80 \mathrm{~kg} \cdot \mathrm{N} \cdot \mathrm{ha}^{-1}+20 \\
\mathrm{~kg} \cdot \mathrm{S} \cdot \mathrm{ha}^{-1}+\text { Penicillium bilaiae }\end{array}$ & 503 & 473 & 412 & ND \\
\hline \multirow[t]{3}{*}{26} & Rock phosphate [powder] (BC Mines) @ $20 \mathrm{~kg} \cdot \mathrm{P} \cdot \mathrm{ha}^{-1}+80 \mathrm{~kg} \cdot \mathrm{N} \cdot \mathrm{ha}^{-1}+20 \mathrm{~kg} \cdot \mathrm{S} \cdot \mathrm{ha}^{-1}$ & 495 & 476 & 423 & 453 \\
\hline & $\operatorname{LSD}_{0.05}$ & 11 & 20 & 39 & 19 \\
\hline & SEM $^{\mathrm{y}}$ & $4.1^{* * *}$ & $7.0^{* * *}$ & $13.8^{* * *}$ & $6.8^{* *}$ \\
\hline
\end{tabular}

${ }^{\mathrm{z}} \mathrm{ND}$ refers to not determined; ${ }^{\mathrm{y},{ }^{* *}}$ and ${ }^{* * *}$ refer to significant treatment effects in ANOVA at $\mathrm{P} \leq 0.01$ and $\mathrm{P} \leq 0.001$, respectively.

optimum crop growth.

Compared to the control, there was a substantial reduction in total $\mathrm{N}$ uptake in seed + straw of canola in 2010 (also slight in 2011), when only $\mathrm{N}$ fertilizer was applied without any sulphate-S. Application of $\mathrm{P}$ along with $\mathrm{N}(\mathrm{NP})$ resulted in some increase in total $\mathrm{N}$ uptake in seed + straw compared to the $\mathrm{N}$ alone and control treatments. The combined application of $\mathrm{N}$ (as ammonium nitrate) $+\mathrm{P}$ (as triple super phosphate $+\mathrm{S}$ (potassium sulphate) chemical fertilizers (NPS) produced 
Table 8. Total N uptake in seed + straw of canola with various amendments applied annually in 2009, 2010, 2011 and 2012 at Star City, Saskatchewan.

\begin{tabular}{|c|c|c|c|c|c|}
\hline \multicolumn{2}{|r|}{ Treatment } & \multicolumn{4}{|c|}{ Total $\mathrm{N}$ uptake in seed + straw $\left(\mathrm{kg} \cdot \mathrm{N} \cdot \mathrm{ha}^{-1}\right)$} \\
\hline No & Amendments & 2009 & 2010 & 2011 & 2012 \\
\hline 1 & Control (no amendment) & 38.5 & 33.6 & 35.1 & 55.8 \\
\hline 2 & Compost@20 Mg.ha ${ }^{-1}$ & 45.3 & 31.3 & 37.7 & 51.2 \\
\hline 3 & Wood ash - fine @2 Mg.ha ${ }^{-1}$ & 44.8 & 30.5 & 33.3 & 60.2 \\
\hline 28 & Wood ash - granular@ $@ 200 \mathrm{~kg} \cdot \mathrm{ha}^{-1}$ (applied side band) & 40.5 & 27.5 & 37.9 & 49.4 \\
\hline 4 & Alfalfa pellets @ $2 \mathrm{Mg} \cdot \mathrm{ha}^{-1}$ & 45.1 & 40.3 & 42.7 & 72.6 \\
\hline 5 & Alfalfa + canola meal pellets@ $2 \mathrm{Mg} \cdot \mathrm{ha}^{-1}$ & 48.3 & 33.0 & 38.9 & 67.3 \\
\hline 6 & Distiller grain (wheat) - wet @ $2 \mathrm{Mg} \cdot \mathrm{ha}^{-1}$ & 41.2 & 28.1 & 46.7 & 64.6 \\
\hline 7 & Distiller grain (wheat) - dry @ $1 \mathrm{Mg} \cdot \mathrm{ha}^{-1}$ & 64.3 & 37.9 & 64.8 & 93.3 \\
\hline 21 & Distiller grain (corn) - dry @ $1 \mathrm{Mg} \cdot \mathrm{ha}^{-1}$ & 60.8 & 32.2 & 43.4 & 76.1 \\
\hline 8 & Thin stillage@20,000 L·ha ${ }^{-1}$ & 85.7 & 57.9 & 80.1 & 113.8 \\
\hline 9 & Glycerol@1 Mg $\cdot \mathrm{ha}^{-1}$ & 32.7 & 35.4 & 24.0 & 52.6 \\
\hline 10 & Fish food additive@ $1 \mathrm{Mg} \cdot \mathrm{ha}^{-1}$ & 64.2 & 46.9 & 65.7 & 88.8 \\
\hline 17 & Gypsum@20 kg $\cdot \mathrm{S} \cdot \mathrm{ha}^{-1}+80 \mathrm{~kg} \cdot \mathrm{N} \cdot \mathrm{ha}^{-1}+20 \mathrm{~kg} \cdot \mathrm{P} \cdot \mathrm{ha}^{-1}$ & 93.5 & 48.8 & 80.0 & 112.1 \\
\hline 18 & Rapid release elemental S@ $20 \mathrm{~kg} \cdot \mathrm{S} \cdot \mathrm{ha}^{-1}+80 \mathrm{~kg} \cdot \mathrm{N} \cdot \mathrm{ha}^{-1}+20 \mathrm{~kg} \cdot \mathrm{P} \cdot \mathrm{ha}^{-1}$ & 94.7 & 44.7 & 94.6 & 102.1 \\
\hline 19 & Glycerol@ $1 \mathrm{Mg} \cdot \mathrm{ha}^{-1}+80 \mathrm{~kg} \cdot \mathrm{N} \cdot \mathrm{ha}^{-1}$ & 72.0 & 25.9 & 50.6 & 82.6 \\
\hline 20 & Wood ash - fine@ $@ 2 \mathrm{Mg} \cdot \mathrm{ha}^{-1}+80 \mathrm{~kg} \cdot \mathrm{N} \cdot \mathrm{ha}^{-1}$ & 92.1 & 57.0 & 85.8 & 105.8 \\
\hline 29 & Wood ash - granular @ $200 \mathrm{~kg} \cdot \mathrm{ha}^{-1}$ (applied side band) $+80 \mathrm{~kg} \cdot \mathrm{N} \cdot \mathrm{ha}^{-1}$ & 89.5 & 41.8 & 78.4 & 103.7 \\
\hline 11 & Triple superphosphate @ $20 \mathrm{~kg} \cdot \mathrm{P} \cdot \mathrm{ha}^{-1}+80 \mathrm{~kg} \cdot \mathrm{N} \cdot \mathrm{ha}^{-1}+20 \mathrm{~kg} \cdot \mathrm{S} \cdot \mathrm{ha}^{-1}$ & 80.3 & 57.3 & 91.5 & 109.4 \\
\hline 31 & $\mathrm{~N}$ only $-80 \mathrm{~kg} \cdot \mathrm{N} \cdot \mathrm{ha}^{-1}$ (using $34-0-0$ ) & $\mathrm{ND}^{\mathrm{z}}$ & 20.6 & 33.2 & 69.3 \\
\hline 30 & $\mathrm{~N}+\mathrm{P}-80 \mathrm{~kg} \cdot \mathrm{N} \cdot \mathrm{ha}^{-1}$ (using $\left.34-0-0\right)+20 \mathrm{~kg} \cdot \mathrm{P} \cdot \mathrm{ha}^{-1}$ (using $0-45-0$ ) & ND & 37.8 & 86.8 & 89.2 \\
\hline 27 & $\mathrm{~N}+\mathrm{S}-80 \mathrm{~kg} \cdot \mathrm{N} \cdot \mathrm{ha}^{-1}$ (using $\left.34-0-0\right)+20 \mathrm{~kg} \cdot \mathrm{S} \cdot \mathrm{ha}^{-1}$ (using $0-0-51-17$ ) & ND & 50.3 & 88.3 & 106.1 \\
\hline 12 & Penicillium bilaiae $+80 \mathrm{~kg} \cdot \mathrm{N} \cdot \mathrm{ha}^{-1}+20 \mathrm{~kg} \cdot \mathrm{S} \cdot \mathrm{ha}^{-1}$ & 84.2 & 53.3 & 83.0 & 106.7 \\
\hline 13 & $\begin{array}{l}\text { Rock phosphate granular (International Compost) @ } 20 \mathrm{~kg} \cdot \mathrm{P} \cdot \mathrm{ha}^{-1}+80 \mathrm{~kg} \cdot \mathrm{N} \cdot \mathrm{ha}^{-1}+20 \\
\mathrm{~kg} \cdot \mathrm{S} \cdot \mathrm{ha}^{-1}\end{array}$ & 80.3 & 46.9 & 83.8 & 108.2 \\
\hline 14 & $\begin{array}{l}\text { Rock phosphate finely-ground (International Compost) @ } 20 \mathrm{~kg} \cdot \mathrm{P} \cdot \mathrm{ha}^{-1}+80 \mathrm{~kg} \cdot \mathrm{N} \cdot \mathrm{ha}^{-1}+ \\
20 \mathrm{~kg} \cdot \mathrm{S} \cdot \mathrm{ha}^{-1}\end{array}$ & 83.6 & 52.4 & 86.8 & 113.8 \\
\hline 15 & Rock phosphate granular (BC Mines) @ $20 \mathrm{~kg} \cdot \mathrm{P} \cdot \mathrm{ha}^{-1}+80 \mathrm{~kg} \cdot \mathrm{N} \cdot \mathrm{ha}^{-1}+20 \mathrm{~kg} \cdot \mathrm{S} \cdot \mathrm{ha}^{-1}$ & 83.8 & 49.2 & 81.7 & 105.2 \\
\hline 16 & Rock phosphate finely-ground (BC Mines) @ $20 \mathrm{~kg} \cdot \mathrm{P} \cdot \mathrm{ha}^{-1}+80 \mathrm{~kg} \cdot \mathrm{N} \cdot \mathrm{ha}^{-1}+20 \mathrm{~kg} \cdot \mathrm{S} \cdot \mathrm{ha}^{-1}$ & 83.3 & 50.9 & 92.0 & 107.3 \\
\hline 22 & $\begin{array}{l}\text { Rock phosphate granular (BC Mines) @ } 20 \mathrm{~kg} \cdot \mathrm{P} \cdot \mathrm{ha}^{-1}+80 \mathrm{~kg} \cdot \mathrm{N} \cdot \mathrm{ha}^{-1}+20 \mathrm{~kg} \cdot \mathrm{S} \cdot \mathrm{ha}^{-1}+ \\
\text { Penicillium bilaiae }\end{array}$ & 90.4 & 44.6 & 76.0 & 107.0 \\
\hline 23 & $\begin{array}{l}\text { Rock phosphate finely-ground (BC Mines) @ } 20 \mathrm{~kg} \cdot \mathrm{P} \cdot \mathrm{ha}^{-1}+80 \mathrm{~kg} \cdot \mathrm{N} \cdot \mathrm{ha}^{-1}+20 \mathrm{~kg} \cdot \mathrm{S} \cdot \mathrm{ha}{ }^{-1} \\
+ \text { Penicillium bilaiae }\end{array}$ & 92.0 & 46.9 & 102.5 & 115.9 \\
\hline 24 & $\begin{array}{l}\text { Rock phosphate + humates granular (BC Mines) @ } 20 \mathrm{~kg} \cdot \mathrm{P} \cdot \mathrm{ha}^{-1}+80 \mathrm{~kg} \cdot \mathrm{N} \cdot \mathrm{ha}^{-1}+20 \\
\mathrm{~kg} \cdot \mathrm{S} \cdot \mathrm{ha}^{-1}\end{array}$ & 85.9 & 42.1 & 86.1 & ND \\
\hline 25 & $\begin{array}{l}\text { Rock phosphate + humates granular (BC Mines) @ } 20 \mathrm{~kg} \cdot \mathrm{P} \cdot \mathrm{ha}^{-1}+80 \mathrm{~kg} \cdot \mathrm{N} \cdot \mathrm{ha}^{-1}+20 \\
\mathrm{~kg} \cdot \mathrm{S} \cdot \mathrm{ha}^{-1}+\text { Penicillium bilaiae }\end{array}$ & 91.4 & 48.1 & 100.3 & ND \\
\hline \multirow[t]{3}{*}{26} & Rock phosphate [powder] (BC Mines) @ $20 \mathrm{~kg} \cdot \mathrm{P} \cdot \mathrm{ha}^{-1}+80 \mathrm{~kg} \cdot \mathrm{N} \cdot \mathrm{ha}^{-1}+20 \mathrm{~kg} \cdot \mathrm{S} \cdot \mathrm{ha}^{-1}$ & 85.1 & 48.8 & 99.6 & 101.5 \\
\hline & $\mathrm{LSD}_{0.05}$ & 12.7 & 12.9 & 16.7 & 14.0 \\
\hline & SEM $^{\mathrm{y}}$ & $4.53^{* * *}$ & $4.60^{* * *}$ & $5.96^{* * *}$ & $4.99^{* * *}$ \\
\hline
\end{tabular}

${ }^{\mathrm{z}} \mathrm{ND}$ refers to not determined; ${ }^{\mathrm{y},{ }^{* * *}}$ refer to significant treatment effects in ANOVA at $\mathrm{P} \leq 0.001$.

considerably higher total $\mathrm{N}$ uptake in seed + straw of canola, compared to the control, in all four years. This suggests that total $\mathrm{N}$ uptake in seed + straw of canola can be improved significantly by using balanced NPS fertilization/ nutrition on this soil, extremely deficient in plant-available $\mathrm{S}$ and possibly containing insufficient amount of available $\mathrm{P}$ for optimum crop growth, especially for canola being a particular S-sensitive crop. Application of RRES along with $\mathrm{N}+\mathrm{P}$ fertilizer usually produced total $\mathrm{N}$ uptake in seed + straw of canola, similar 
Table 9. Total P uptake in seed + straw of canola with various amendments applied annually in 2009, 2010, 2011 and 2012 at Star City, Saskatchewan.

\begin{tabular}{|c|c|c|c|c|c|}
\hline \multirow{2}{*}{\multicolumn{2}{|c|}{$\begin{array}{l}\text { Treatment } \\
\text { Amendments }\end{array}$}} & \multicolumn{4}{|c|}{ Total $\mathrm{P}$ uptake in seed + straw $\left(\mathrm{kg} \cdot \mathrm{P} \cdot \mathrm{ha}^{-1}\right)$} \\
\hline & & 2009 & 2010 & 2011 & 2012 \\
\hline 1 & Control (no amendment) & 9.8 & 6.4 & 6.5 & 10.7 \\
\hline 2 & Compost@20 Mg·ha ${ }^{-1}$ & 11.4 & 7.7 & 8.9 & 12.7 \\
\hline 3 & Wood ash - fine@2 Mg·ha ${ }^{-1}$ & 10.7 & 7.2 & 6.9 & 12.5 \\
\hline 28 & Wood ash - granular@200 kg·ha ${ }^{-1}$ (applied side band) & 9.2 & 5.5 & 5.9 & 9.3 \\
\hline 4 & Alfalfa pellets @ $2 \mathrm{Mg} \cdot \mathrm{ha}^{-1}$ & 10.8 & 7.7 & 7.3 & 12.9 \\
\hline 5 & Alfalfa + canola meal pellets@ $2 \mathrm{Mg} \cdot \mathrm{ha}^{-1}$ & 10.9 & 6.4 & 6.6 & 12.5 \\
\hline 6 & Distiller grain (wheat) - wet @ $2 \mathrm{Mg} \cdot \mathrm{ha}^{-1}$ & 9.6 & 4.8 & 7.8 & 11.5 \\
\hline 7 & Distiller grain (wheat) - dry @ $1 \mathrm{Mg} \cdot \mathrm{ha}^{-1}$ & 15.5 & 7.5 & 10.0 & 16.9 \\
\hline 21 & Distiller grain (corn) - dry @ $1 \mathrm{Mg} \cdot \mathrm{ha}^{-1}$ & 13.8 & 6.9 & 6.8 & 14.0 \\
\hline 8 & Thin stillage @ 20,000 L·ha ${ }^{-1}$ & 18.3 & 11.7 & 11.1 & 22.2 \\
\hline 9 & Glycerol@1 Mg $\cdot \mathrm{ha}^{-1}$ & 8.4 & 6.8 & 4.9 & 11.2 \\
\hline 10 & Fish food additive @ $1 \mathrm{Mg} \cdot \mathrm{ha}^{-1}$ & 14.7 & 8.7 & 8.5 & 15.1 \\
\hline 17 & Gypsum@ $20 \mathrm{~kg} \cdot \mathrm{S} \cdot \mathrm{ha}^{-1}+80 \mathrm{~kg} \cdot \mathrm{N} \cdot \mathrm{ha}^{-1}+20 \mathrm{~kg} \cdot \mathrm{P} \cdot \mathrm{ha}^{-1}$ & 19.6 & 10.8 & 11.3 & 23.1 \\
\hline 18 & Rapid release elemental S @ $20 \mathrm{~kg} \cdot \mathrm{S} \cdot \mathrm{ha}^{-1}+80 \mathrm{~kg} \cdot \mathrm{N} \cdot \mathrm{ha}^{-1}+20 \mathrm{~kg} \cdot \mathrm{P} \cdot \mathrm{ha}^{-1}$ & 19.1 & 9.2 & 12.9 & 20.8 \\
\hline 19 & Glycerol@ $1 \mathrm{Mg} \cdot \mathrm{ha}^{-1}+80 \mathrm{~kg} \cdot \mathrm{N} \cdot \mathrm{ha}^{-1}$ & 14.5 & 4.0 & 5.9 & 12.1 \\
\hline 20 & Wood ash - fine @ $2 \mathrm{Mg} \cdot \mathrm{ha}^{-1}+80 \mathrm{~kg} \cdot \mathrm{N} \cdot \mathrm{ha}^{-1}$ & 17.7 & 11.3 & 10.3 & 17.1 \\
\hline 29 & Wood ash - granular@ $200 \mathrm{~kg} \cdot \mathrm{ha}^{-1}$ (applied side band) $+80 \mathrm{~kg} \cdot \mathrm{N} \cdot \mathrm{ha}^{-1}$ & 16.8 & 7.0 & 8.7 & 15.8 \\
\hline 11 & Triple superphosphate @ $20 \mathrm{~kg} \cdot \mathrm{P} \cdot \mathrm{ha}^{-1}+80 \mathrm{~kg} \cdot \mathrm{N} \cdot \mathrm{ha}^{-1}+20 \mathrm{~kg} \cdot \mathrm{S} \cdot \mathrm{ha}^{-1}$ & 17.9 & 11.4 & 13.2 & 22.2 \\
\hline 31 & $\mathrm{~N}$ only $-80 \mathrm{~kg} \mathrm{~N} \cdot \mathrm{ha}^{-1}$ (using $34-0-0$ ) & $\mathrm{ND}^{\mathrm{z}}$ & 3.2 & 4.1 & 10.9 \\
\hline 30 & $\mathrm{~N}+\mathrm{P}-80 \mathrm{~kg} \mathrm{~N} \cdot \mathrm{ha}^{-1}$ (using $\left.34-0-0\right)+20 \mathrm{~kg} \cdot \mathrm{P} \cdot \mathrm{ha}^{-1}$ (using $0-45-0$ ) & ND & 6.8 & 11.3 & 17.4 \\
\hline 27 & $\mathrm{~N}+\mathrm{S}-80 \mathrm{~kg} \mathrm{~N} \cdot \mathrm{ha}^{-1}$ (using $\left.34-0-0\right)+20 \mathrm{~kg} \cdot \mathrm{S} \cdot \mathrm{ha}^{-1}$ (using $0-0-51-17$ ) & ND & 7.8 & 9.3 & 16.1 \\
\hline 12 & Penicillium bilaiae $+80 \mathrm{~kg} \cdot \mathrm{N} \cdot \mathrm{ha}^{-1}+20 \mathrm{~kg} \cdot \mathrm{S} \cdot \mathrm{ha}^{-1}$ & 16.4 & 7.8 & 8.6 & 14.5 \\
\hline 13 & $\begin{array}{l}\text { Rock phosphate granular (International Compost) @ } 20 \mathrm{~kg} \cdot \mathrm{P} \cdot \mathrm{ha}^{-1}+80 \mathrm{~kg} \cdot \mathrm{N} \cdot \mathrm{ha}^{-1}+20 \\
\mathrm{~kg} \cdot \mathrm{S} \cdot \mathrm{ha}^{-1}\end{array}$ & 15.8 & 7.5 & 9.0 & 17.2 \\
\hline 14 & $\begin{array}{l}\text { Rock phosphate finely-ground (International Compost) @ } 20 \mathrm{~kg} \cdot \mathrm{P} \cdot \mathrm{ha}^{-1}+80 \mathrm{~kg} \cdot \mathrm{N} \cdot \mathrm{ha}^{-1}+ \\
20 \mathrm{~kg} \cdot \mathrm{S} \cdot \mathrm{ha}^{-1}\end{array}$ & 17.6 & 9.5 & 11.2 & 20.1 \\
\hline 15 & Rock phosphate granular (BC Mines) @ $20 \mathrm{~kg} \cdot \mathrm{P} \cdot \mathrm{ha}^{-1}+80 \mathrm{~kg} \cdot \mathrm{N} \cdot \mathrm{ha}^{-1}+20 \mathrm{~kg} \cdot \mathrm{S} \cdot \mathrm{ha}^{-1}$ & 17.1 & 8.1 & 8.8 & 16.6 \\
\hline 16 & Rock phosphate finely-ground (BC Mines) @ $20 \mathrm{~kg} \cdot \mathrm{P} \cdot \mathrm{ha}^{-1}+80 \mathrm{~kg} \cdot \mathrm{N} \cdot \mathrm{ha}^{-1}+20 \mathrm{~kg} \cdot \mathrm{S} \cdot \mathrm{ha}^{-1}$ & 17.4 & 8.6 & 10.7 & 17.8 \\
\hline 22 & $\begin{array}{l}\text { Rock phosphate granular (BC Mines) @ } 20 \mathrm{~kg} \cdot \mathrm{P} \cdot \mathrm{ha}^{-1}+80 \mathrm{~kg} \cdot \mathrm{N} \cdot \mathrm{ha}^{-1}+20 \mathrm{~kg} \cdot \mathrm{S} \cdot \mathrm{ha}^{-1}+ \\
\text { Penicillium bilaiae }\end{array}$ & 17.2 & 7.3 & 8.3 & 16.1 \\
\hline 23 & $\begin{array}{l}\text { Rock phosphate finely-ground (BC Mines) @ } 20 \mathrm{~kg} \cdot \mathrm{P} \cdot \mathrm{ha}^{-1}+80 \mathrm{~kg} \cdot \mathrm{N} \cdot \mathrm{ha}^{-1}+20 \mathrm{~kg} \cdot \mathrm{S} \cdot \mathrm{ha}^{-1} \\
+ \text { Penicillium bilaiae }\end{array}$ & 17.8 & 8.1 & 11.2 & 18.4 \\
\hline 24 & $\begin{array}{l}\text { Rock phosphate + humates granular (BC Mines) @ } 20 \mathrm{~kg} \cdot \mathrm{P} \cdot \mathrm{ha}^{-1}+80 \mathrm{~kg} \cdot \mathrm{N} \cdot \mathrm{ha}^{-1}+20 \\
\mathrm{~kg} \cdot \mathrm{S} \cdot \mathrm{ha}^{-1}\end{array}$ & 17.3 & 6.6 & 9.4 & ND \\
\hline 25 & $\begin{array}{l}\text { Rock phosphate + humates granular (BC Mines) @ } 20 \mathrm{~kg} \cdot \mathrm{P} \cdot \mathrm{ha}^{-1}+80 \mathrm{~kg} \cdot \mathrm{N} \cdot \mathrm{ha}^{-1}+20 \\
\mathrm{~kg} \cdot \mathrm{S} \cdot \mathrm{ha}^{-1}+\text { Penicillium bilaiae }\end{array}$ & 18.1 & 7.3 & 10.3 & ND \\
\hline \multirow[t]{3}{*}{26} & Rock phosphate [powder] (BC Mines)@ $20 \mathrm{~kg} \cdot \mathrm{P} \cdot \mathrm{ha}^{-1}+80 \mathrm{~kg} \cdot \mathrm{N} \cdot \mathrm{ha}^{-1}+20 \mathrm{~kg} \cdot \mathrm{S} \cdot \mathrm{ha}^{-1}$ & 17.6 & 8.4 & 11.8 & 16.6 \\
\hline & $\mathrm{LSD}_{0.05}$ & 2.5 & 2.7 & 2.0 & 2.2 \\
\hline & SEM $^{y}$ & $0.87^{* * *}$ & $0.98^{* * *}$ & $0.70^{* * *}$ & $0.77^{* * *}$ \\
\hline
\end{tabular}

${ }^{\mathrm{z}} \mathrm{ND}$ refers to not determined; ${ }^{\mathrm{y},{ }^{* *} *}$ refer to significant treatment effects in ANOVA at $\mathrm{P} \leq 0.001$.

to gypsum $+\mathrm{N}+\mathrm{P}$ treatment. Total $\mathrm{N}$ uptake in seed + straw with both gypsum and RRES treatments were significantly greater than with the $\mathrm{N}$ only treatment, but only slightly less than with the NPS treatment in some years.
Application of $\mathrm{N}+\mathrm{S}$, in combination with rock phosphate and/or Penicillium bilaiae, did not produce any significant increase in total $\mathrm{N}$ uptake in seed + straw compared to the $\mathrm{N}+\mathrm{S}$ treatment. This suggests little or no contribution of rock phosphate and/or Penicillium bilaiae 
Table 10. Total K uptake in seed + straw of canola with various amendments applied annually in 2009, 2010, 2011 and 2012 at Star City, Saskatchewan.

\begin{tabular}{|c|c|c|c|c|c|}
\hline \multirow{2}{*}{\multicolumn{2}{|c|}{$\begin{array}{l}\text { Treatment } \\
\text { Amendments }\end{array}$}} & \multicolumn{4}{|c|}{ Total $\mathrm{K}$ uptake in seed + straw $\left(\mathrm{kg} \cdot \mathrm{K} \cdot \mathrm{ha}^{-1}\right)$} \\
\hline & & 2009 & 2010 & 2011 & 2012 \\
\hline 1 & Control (no amendment) & 22.0 & 15.3 & 61.0 & 26.9 \\
\hline 2 & Compost@20 Mg·ha ${ }^{-1}$ & 24.8 & 17.9 & 66.3 & 25.3 \\
\hline 3 & Wood ash - fine @2 Mg.ha ${ }^{-1}$ & 22.3 & 17.8 & 52.6 & 28.7 \\
\hline 28 & Wood ash - granular@ $200 \mathrm{~kg} \cdot \mathrm{ha}^{-1}$ (applied side band) & 18.7 & 14.2 & 48.7 & 25.1 \\
\hline 4 & Alfalfa pellets@ $2 \mathrm{Mg} \cdot \mathrm{ha}^{-1}$ & 23.1 & 18.0 & 71.9 & 33.2 \\
\hline 5 & Alfalfa + canola meal pellets @ $2 \mathrm{Mg} \cdot \mathrm{ha}^{-1}$ & 25.5 & 18.2 & 60.4 & 34.0 \\
\hline 6 & Distiller grain (wheat) - wet @ $2 \mathrm{Mg} \cdot \mathrm{ha}^{-1}$ & 21.1 & 13.7 & 66.8 & 30.7 \\
\hline 7 & Distiller grain (wheat) - dry @ $1 \mathrm{Mg} \cdot \mathrm{ha}^{-1}$ & 36.9 & 19.5 & 76.5 & 42.7 \\
\hline 21 & Distiller grain (corn) - dry @ $1 \mathrm{Mg} \cdot \mathrm{ha}^{-1}$ & 32.4 & 20.4 & 59.5 & 35.0 \\
\hline 8 & Thin stillage@20,000 L·ha ${ }^{-1}$ & 54.1 & 25.1 & 96.9 & 58.3 \\
\hline 9 & Glycerol@1 Mg·ha ${ }^{-1}$ & 21.2 & 13.6 & 39.7 & 29.5 \\
\hline 10 & Fish food additive@ $1 \mathrm{Mg} \cdot \mathrm{ha}^{-1}$ & 46.3 & 27.0 & 82.5 & 44.4 \\
\hline 17 & Gypsum@ $20 \mathrm{~kg} \cdot \mathrm{S} \cdot \mathrm{ha}^{-1}+80 \mathrm{~kg} \cdot \mathrm{N} \cdot \mathrm{ha}^{-1}+20 \mathrm{~kg} \cdot \mathrm{P} \cdot \mathrm{ha}^{-1}$ & 52.3 & 21.8 & 98.6 & 63.8 \\
\hline 18 & Rapid release elemental S @ $20 \mathrm{~kg} \cdot \mathrm{S} \cdot \mathrm{ha}^{-1}+80 \mathrm{~kg} \cdot \mathrm{N} \cdot \mathrm{ha}^{-1}+20 \mathrm{~kg} \cdot \mathrm{P} \cdot \mathrm{ha}^{-1}$ & 52.5 & 19.5 & 105.7 & 44.3 \\
\hline 19 & Glycerol@1 Mg $\cdot \mathrm{ha}^{-1}+80 \mathrm{~kg} \cdot \mathrm{N} \cdot \mathrm{ha}^{-1}$ & 44.0 & 12.7 & 58.5 & 39.9 \\
\hline 20 & Wood ash - fine@2 Mg $\cdot \mathrm{ha}^{-1}+80 \mathrm{~kg} \cdot \mathrm{N} \cdot \mathrm{ha}^{-1}$ & 53.4 & 25.7 & 111.0 & 43.5 \\
\hline 29 & Wood ash - granular @ $200 \mathrm{~kg} \cdot \mathrm{ha}^{-1}$ (applied side band) + $80 \mathrm{~kg} \cdot \mathrm{N} \cdot \mathrm{ha}^{-1}$ & 54.5 & 17.6 & 96.8 & 47.6 \\
\hline 11 & Triple superphosphate @ $20 \mathrm{~kg} \cdot \mathrm{P} \cdot \mathrm{ha}^{-1}+80 \mathrm{~kg} \cdot \mathrm{N} \cdot \mathrm{ha}^{-1}+20 \mathrm{~kg} \cdot \mathrm{S} \cdot \mathrm{ha}^{-1}$ & 50.8 & 22.4 & 110.5 & 58.1 \\
\hline 31 & $\mathrm{~N}$ only $-80 \mathrm{~kg} \cdot \mathrm{N} \cdot \mathrm{ha}^{-1}$ (using $34-0-0$ ) & $\mathrm{ND}^{\mathrm{z}}$ & 10.9 & 40.9 & 37.8 \\
\hline 30 & $\mathrm{~N}+\mathrm{P}-80 \mathrm{~kg} \cdot \mathrm{N} \cdot \mathrm{ha}^{-1}$ (using $\left.34-0-0\right)+20 \mathrm{~kg} \cdot \mathrm{P} \cdot \mathrm{ha}^{-1}$ (using $0-45-0$ ) & ND & 13.9 & 105.3 & 39.4 \\
\hline 27 & $\mathrm{~N}+\mathrm{S}-80 \mathrm{~kg} \cdot \mathrm{N} \cdot \mathrm{ha}^{-1}$ (using $\left.34-0-0\right)+20 \mathrm{~kg} \cdot \mathrm{S} \cdot \mathrm{ha}^{-1}$ (using $0-0-51-17$ ) & ND & 19.4 & 96.3 & 53.5 \\
\hline 12 & Penicillium bilaiae $+80 \mathrm{~kg} \cdot \mathrm{N} \cdot \mathrm{ha}^{-1}+20 \mathrm{~kg} \cdot \mathrm{S} \cdot \mathrm{ha}^{-1}$ & 57.3 & 22.2 & 97.5 & 49.8 \\
\hline 13 & $\begin{array}{l}\text { Rock phosphate granular (International Compost) @ } 20 \mathrm{~kg} \cdot \mathrm{P} \cdot \mathrm{ha}^{-1}+80 \mathrm{~kg} \cdot \mathrm{N} \cdot \mathrm{ha}^{-1}+20 \\
\mathrm{~kg} \cdot \mathrm{S} \cdot \mathrm{ha}^{-1}\end{array}$ & 54.0 & 22.1 & 102.9 & 55.8 \\
\hline 14 & $\begin{array}{l}\text { Rock phosphate finely-ground (International Compost)@20 kg } \cdot \mathrm{P} \cdot \mathrm{ha}^{-1}+80 \mathrm{~kg} \cdot \mathrm{N} \cdot \mathrm{ha}^{-1}+ \\
20 \mathrm{~kg} \cdot \mathrm{S} \cdot \mathrm{ha}^{-1}\end{array}$ & 50.9 & 22.4 & 106.2 & 65.4 \\
\hline 15 & Rock phosphate granular (BC Mines) @ $20 \mathrm{~kg} \cdot \mathrm{P} \cdot \mathrm{ha}^{-1}+80 \mathrm{~kg} \cdot \mathrm{N} \cdot \mathrm{ha}^{-1}+20 \mathrm{~kg} \cdot \mathrm{S} \cdot \mathrm{ha}^{-1}$ & 54.1 & 23.5 & 98.4 & 54.0 \\
\hline 16 & Rock phosphate finely-ground (BC Mines) @ $20 \mathrm{~kg} \cdot \mathrm{P} \cdot \mathrm{ha}^{-1}+80 \mathrm{~kg} \cdot \mathrm{N} \cdot \mathrm{ha}^{-1}+20 \mathrm{~kg} \cdot \mathrm{S} \cdot \mathrm{ha}^{-1}$ & 52.1 & 18.2 & 122.4 & 51.5 \\
\hline 22 & $\begin{array}{l}\text { Rock phosphate granular (BC Mines)@ } 20 \mathrm{~kg} \cdot \mathrm{P} \cdot \mathrm{ha}^{-1}+80 \mathrm{~kg} \cdot \mathrm{N} \cdot \mathrm{ha}^{-1}+20 \mathrm{~kg} \cdot \mathrm{S} \cdot \mathrm{ha}^{-1}+ \\
\text { Penicillium bilaiae }\end{array}$ & 55.3 & 21.0 & 98.8 & 55.9 \\
\hline 23 & $\begin{array}{l}\text { Rock phosphate finely-ground (BC Mines) @ } 20 \mathrm{~kg} \cdot \mathrm{P} \cdot \mathrm{ha}^{-1}+80 \mathrm{~kg} \cdot \mathrm{N} \cdot \mathrm{ha}^{-1}+20 \mathrm{~kg} \cdot \mathrm{S} \cdot \mathrm{ha}^{-1} \\
+ \text { Penicillium bilaiae }\end{array}$ & 64.8 & 21.0 & 120.3 & 52.6 \\
\hline 24 & $\begin{array}{l}\text { Rock phosphate + humates granular (BC Mines) @ } 20 \mathrm{~kg} \cdot \mathrm{P} \cdot \mathrm{ha}^{-1}+80 \mathrm{~kg} \cdot \mathrm{N} \cdot \mathrm{ha}^{-1}+20 \\
\mathrm{~kg} \cdot \mathrm{S} \cdot \mathrm{ha}^{-1}\end{array}$ & 56.7 & 16.5 & 93.5 & ND \\
\hline 25 & $\begin{array}{l}\text { Rock phosphate + humates granular (BC Mines) @ } 20 \mathrm{~kg} \cdot \mathrm{P} \cdot \mathrm{ha}^{-1}+80 \mathrm{~kg} \cdot \mathrm{N} \cdot \mathrm{ha}^{-1}+20 \\
\mathrm{~kg} \cdot \mathrm{S} \cdot \mathrm{ha}^{-1}+\text { Penicillium bilaiae }\end{array}$ & 56.6 & 18.2 & 116.9 & ND \\
\hline \multirow[t]{3}{*}{26} & Rock phosphate [powder] (BC Mines) @ $20 \mathrm{~kg} \cdot \mathrm{P} \cdot \mathrm{ha}^{-1}+80 \mathrm{~kg} \cdot \mathrm{N} \cdot \mathrm{ha}^{-1}+20 \mathrm{~kg} \cdot \mathrm{S} \cdot \mathrm{ha}^{-1}$ & 54.3 & 17.6 & 120.4 & 54.4 \\
\hline & $\mathrm{LSD}_{0.05}$ & 8.6 & 7.9 & 23.4 & 15.8 \\
\hline & SEM $^{y}$ & $3.06^{* * *}$ & $2.82^{* *}$ & $8.32^{* * *}$ & $5.62^{* * *}$ \\
\hline
\end{tabular}

${ }^{\mathrm{z}} \mathrm{ND}$ refers to not determined; ${ }^{\mathrm{y},{ }^{* *}}$ and ${ }^{* * *}$ refer to significant treatment effects in ANOVA at $\mathrm{P} \leq 0.01$ and $\mathrm{P} \leq 0.001$, respectively. 
Table 11. Total S uptake in seed + straw of canola with various amendments applied annually in 2009, 2010, 2011 and 2012 at Star City, Saskatchewan.

\begin{tabular}{|c|c|c|c|c|c|}
\hline \multirow{2}{*}{\multicolumn{2}{|c|}{$\begin{array}{l}\text { Treatment } \\
\text { Amendments }\end{array}$}} & \multicolumn{4}{|c|}{ Total S uptake in seed + straw $\left(\mathrm{kg} \cdot \mathrm{S} \cdot \mathrm{ha}^{-1}\right)$} \\
\hline & & 2009 & 2010 & 2011 & 2012 \\
\hline 1 & Control (no amendment) & 9.6 & 5.1 & 8.2 & 8.8 \\
\hline 2 & Compost@20 Mg·ha ${ }^{-1}$ & 13.2 & 5.4 & 11.2 & 11.7 \\
\hline 3 & Wood ash - fine @ $2 \mathrm{Mg} \cdot \mathrm{ha}^{-1}$ & 13.2 & 5.2 & 10.1 & 15.7 \\
\hline 28 & Wood ash - granular@200 kg·ha ${ }^{-1}$ (applied side band) & 10.5 & 4.1 & 7.8 & 10.1 \\
\hline 4 & Alfalfa pellets@ $2 \mathrm{Mg} \cdot \mathrm{ha}^{-1}$ & 11.1 & 6.0 & 9.7 & 11.2 \\
\hline 5 & Alfalfa + canola meal pellets @ $2 \mathrm{Mg} \cdot \mathrm{ha}^{-1}$ & 12.2 & 4.4 & 9.6 & 9.8 \\
\hline 6 & Distiller grain (wheat) - wet @ $2 \mathrm{Mg} \cdot \mathrm{ha}^{-1}$ & 9.7 & 3.7 & 10.6 & 10.3 \\
\hline 7 & Distiller grain (wheat) - dry @ $1 \mathrm{Mg} \cdot \mathrm{ha}^{-1}$ & 17.4 & 5.5 & 14.6 & 15.5 \\
\hline 21 & Distiller grain (corn) - dry @ $1 \mathrm{Mg} \cdot \mathrm{ha}^{-1}$ & 14.9 & 4.9 & 11.3 & 14.4 \\
\hline 8 & Thin stillage @ 20,000 L·ha ${ }^{-1}$ & 22.5 & 9.2 & 14.7 & 18.8 \\
\hline 9 & Glycerol @ $1 \mathrm{Mg} \cdot \mathrm{ha}^{-1}$ & 7.8 & 4.9 & 6.1 & 8.0 \\
\hline 10 & Fish food additive @ $1 \mathrm{Mg} \cdot \mathrm{ha}^{-1}$ & 15.6 & 7.0 & 11.4 & 12.7 \\
\hline 17 & Gypsum @ $20 \mathrm{~kg} \cdot \mathrm{S} \cdot \mathrm{ha}^{-1}+80 \mathrm{~kg} \cdot \mathrm{N} \cdot \mathrm{ha}^{-1}+20 \mathrm{~kg} \cdot \mathrm{P} \cdot \mathrm{ha}^{-1}$ & 23.9 & 9.0 & 20.7 & 27.9 \\
\hline 18 & Rapid release elemental S@20 kg $\cdot \mathrm{S} \cdot \mathrm{ha}^{-1}+80 \mathrm{~kg} \cdot \mathrm{N} \cdot \mathrm{ha}^{-1}+20 \mathrm{~kg} \cdot \mathrm{P} \cdot \mathrm{ha}^{-1}$ & 21.3 & 6.7 & 19.0 & 17.0 \\
\hline 19 & Glycerol@ $1 \mathrm{Mg} \cdot \mathrm{ha}^{-1}+80 \mathrm{~kg} \cdot \mathrm{N} \cdot \mathrm{ha}^{-1}$ & 16.8 & 3.2 & 8.8 & 10.3 \\
\hline 20 & Wood ash - fine @ $2 \mathrm{Mg} \cdot \mathrm{ha}^{-1}+80 \mathrm{~kg} \cdot \mathrm{N} \cdot \mathrm{ha}^{-1}$ & 26.0 & 10.5 & 21.6 & 20.8 \\
\hline 29 & Wood ash - granular@ $200 \mathrm{~kg} \cdot \mathrm{ha}^{-1}$ (applied side band) $+80 \mathrm{~kg} \cdot \mathrm{N} \cdot \mathrm{ha}^{-1}$ & 20.5 & 6.1 & 14.7 & 14.7 \\
\hline 11 & Triple superphosphate @ $20 \mathrm{~kg} \cdot \mathrm{P} \cdot \mathrm{ha}^{-1}+80 \mathrm{~kg} \cdot \mathrm{N} \cdot \mathrm{ha}^{-1}+20 \mathrm{~kg} \cdot \mathrm{S} \cdot \mathrm{ha}^{-1}$ & 23.4 & 9.7 & 22.4 & 22.1 \\
\hline 31 & $\mathrm{~N}$ only $-80 \mathrm{~kg} \cdot \mathrm{N} \cdot \mathrm{ha}^{-1}$ (using $34-0-0$ ) & $\mathrm{ND}^{\mathrm{z}}$ & 2.3 & 4.1 & 7.6 \\
\hline 30 & $\mathrm{~N}+\mathrm{P}-80 \mathrm{~kg} \cdot \mathrm{N} \cdot \mathrm{ha}^{-1}$ (using $\left.34-0-0\right)+20 \mathrm{~kg} \cdot \mathrm{P} \cdot \mathrm{ha}^{-1}$ (using $0-45-0$ ) & ND & 5.4 & 14.0 & 10.9 \\
\hline 27 & $\mathrm{~N}+\mathrm{S}-80 \mathrm{~kg} \cdot \mathrm{N} \cdot \mathrm{ha}^{-1}$ (using $\left.34-0-0\right)+20 \mathrm{~kg} \cdot \mathrm{S} \cdot \mathrm{ha}^{-1}$ (using $0-0-51-17$ ) & ND & 8.0 & 20.4 & 22.0 \\
\hline 12 & Penicillium bilaiae $+80 \mathrm{~kg} \cdot \mathrm{N} \cdot \mathrm{ha}^{-1}+20 \mathrm{~kg} \cdot \mathrm{S} \cdot \mathrm{ha}^{-1}$ & 23.0 & 8.5 & 19.7 & 22.0 \\
\hline 13 & $\begin{array}{l}\text { Rock phosphate granular (International Compost) @ } 20 \mathrm{~kg} \cdot \mathrm{P} \cdot \mathrm{ha}^{-1}+80 \mathrm{~kg} \cdot \mathrm{N} \cdot \mathrm{ha}^{-1}+20 \\
\mathrm{~kg} \cdot \mathrm{S} \cdot \mathrm{ha}^{-1}\end{array}$ & 23.0 & 7.3 & 21.2 & 24.9 \\
\hline 14 & $\begin{array}{l}\text { Rock phosphate finely-ground (International Compost) @ } 20 \mathrm{~kg} \cdot \mathrm{P} \cdot \mathrm{ha}^{-1}+80 \mathrm{~kg} \cdot \mathrm{N} \cdot \mathrm{ha}^{-1}+20 \\
\mathrm{~kg} \cdot \mathrm{S} \cdot \mathrm{ha}^{-1}\end{array}$ & 22.8 & 8.2 & 19.3 & 25.5 \\
\hline 15 & Rock phosphate granular (BC Mines) @ $20 \mathrm{~kg} \cdot \mathrm{P} \cdot \mathrm{ha}^{-1}+80 \mathrm{~kg} \cdot \mathrm{N} \cdot \mathrm{ha}^{-1}+20 \mathrm{~kg} \cdot \mathrm{S} \cdot \mathrm{ha}^{-1}$ & 21.1 & 8.7 & 20.3 & 21.9 \\
\hline 16 & Rock phosphate finely-ground (BC Mines) @ $20 \mathrm{~kg} \cdot \mathrm{P} \cdot \mathrm{ha}^{-1}+80 \mathrm{~kg} \cdot \mathrm{N} \cdot \mathrm{ha}^{-1}+20 \mathrm{~kg} \cdot \mathrm{S} \cdot \mathrm{ha}^{-1}$ & 22.2 & 8.4 & 19.8 & 22.2 \\
\hline 22 & $\begin{array}{l}\text { Rock phosphate granular (BC Mines) @ } 20 \mathrm{~kg} \cdot \mathrm{P} \cdot \mathrm{ha}^{-1}+80 \mathrm{~kg} \cdot \mathrm{N} \cdot \mathrm{ha}^{-1}+20 \mathrm{~kg} \cdot \mathrm{S} \cdot \mathrm{ha}^{-1}+ \\
\text { Penicillium bilaiae }\end{array}$ & 23.2 & 7.4 & 17.5 & 22.6 \\
\hline 23 & $\begin{array}{l}\text { Rock phosphate finely-ground (BC Mines) @ } 20 \mathrm{~kg} \cdot \mathrm{P} \cdot \mathrm{ha}^{-1}+80 \mathrm{~kg} \cdot \mathrm{N} \cdot \mathrm{ha}^{-1}+20 \mathrm{~kg} \cdot \mathrm{S} \cdot \mathrm{ha}^{-1}+ \\
\text { Penicillium bilaiae }\end{array}$ & 25.1 & 8.2 & 23.5 & 22.5 \\
\hline 24 & $\begin{array}{l}\text { Rock phosphate + humates granular (BC Mines) @ } 20 \mathrm{~kg} \cdot \mathrm{P} \cdot \mathrm{ha}^{-1}+80 \mathrm{~kg} \cdot \mathrm{N} \cdot \mathrm{ha}^{-1}+20 \\
\mathrm{~kg} \cdot \mathrm{S} \cdot \mathrm{ha}^{-1}\end{array}$ & 22.4 & 6.5 & 21.2 & ND \\
\hline 25 & $\begin{array}{l}\text { Rock phosphate }+ \text { humates granular (BC Mines) @ } 20 \mathrm{~kg} \cdot \mathrm{P} \cdot \mathrm{ha}^{-1}+80 \mathrm{~kg} \cdot \mathrm{N} \cdot \mathrm{ha}^{-1}+20 \\
\mathrm{~kg} \cdot \mathrm{S} \cdot \mathrm{ha}^{-1}+\text { Penicillium bilaiae }\end{array}$ & 26.8 & 7.3 & 24.6 & ND \\
\hline \multirow[t]{3}{*}{26} & Rock phosphate [powder] (BC Mines) @ $20 \mathrm{~kg} \cdot \mathrm{P} \cdot \mathrm{ha}^{-1}+80 \mathrm{~kg} \cdot \mathrm{N} \cdot \mathrm{ha}^{-1}+20 \mathrm{~kg} \cdot \mathrm{S} \cdot \mathrm{ha}^{-1}$ & 24.2 & 7.4 & 24.2 & 20.6 \\
\hline & $\operatorname{LSD}_{0.05}$ & 4.4 & 2.5 & 5.4 & 6.5 \\
\hline & SEM $^{\mathrm{y}}$ & $1.58^{* * *}$ & $0.88^{* * *}$ & $1.93^{* * *}$ & $2.30^{* * *}$ \\
\hline
\end{tabular}

${ }^{\mathrm{z}} \mathrm{ND}$ refers to not determined; ${ }^{\mathrm{y},{ }^{* * *}}$ refers to significant treatment effects in ANOVA at $\mathrm{P} \leq 0.001$. 
in increasing $\mathrm{P}$ availability to canola. The response trends of total P, K and S uptake in seed + straw of canola to various organic and inorganic amendments were usually similar to total $\mathrm{N}$ uptake in seed + straw in most cases (Tables 9-11).

\section{DISCUSSION}

Our study investigated many alternative nutrient sources (ANS) that can be potentially used to prevent/ eliminate nutrient deficiencies in organic and/or conventional cropping systems. In our study, we included a treatment with combined application of $\mathrm{N}, \mathrm{P}$ and $\mathrm{S}$ chemical fertilizers (NPS) to prevent all major nutrient deficiencies in soil at the experimental site in order to obtain the best yield and nutrient uptake, so that all other organic and inorganic/mineral amendments can be compared to this NPS treatment for their relative effectiveness. The NPS treatment in our study produced considerably higher seed yield, straw yield and nutrient uptake of canola compared to the no amendment control. In the following sections, we discussed results on amendments applicable to organic crop production as well as to conventional farming systems separately.

In treatments receiving only organic amendments (applicable to organic crop production), thin stillage produced the highest seed yield, straw yield and nutrient uptake in both years, and it was similar to the NPS balanced fertilization treatment. This suggests a great potential of thin stillage as an organic amendment to prevent any nutrient deficiencies and subsequently increase crop yield by increasing the availability of nutrients to crop plants. Compared to the control, fish food additive (in both years) and distiller grain dry of both wheat and corn (in 2009) produced significantly higher seed yield, straw yield and nutrient uptake. The significant increase in nutrient uptake in seed + straw with fish food additive, distiller grain dry of both wheat and distiller grain of corn compared to control also suggest the potential of these amendments in increasing the availability of nutrients and subsequently improving yield of organic crops. There was a moderate (but non-significant) increase in seed yield, straw yield and nutrient uptake from compost, alfalfa + canola meal pellets, alfalfa pellets and wood ash fine, suggesting the potential of these amendments after perhaps a long-term use. Similarly, earlier studies have shown potential yield benefits of both organic and mineral amendments and soil activators/inoculants on crop yields, produce quality and nutrient uptake [34,36,52-59]. There was a slight reduction in seed yield, straw yield and nutrient uptake from glycerol, and this was most likely due to immobilization of $\mathrm{N}$ and $\mathrm{S}$ due to wide $\mathrm{C}: \mathrm{N}$ ratio in this product. Composted manure is a good supplier of $\mathrm{N}, \mathrm{P}, \mathrm{K}, \mathrm{S}$, and other nutrients, and is expected to increase crop yields when these nutrients are liming in soil for optimum crop growth/yield [34]. Similarly, alfalfa pellets have narrow $\mathrm{C}: \mathrm{N}$ ratio in plant materials and are expected to supply $\mathrm{N}, \mathrm{P}$ and other nutrients after mineralization [60]. However, in our study, composted manure and alfalfa pellets generally were not very effective in increasing crop yield and nutrient uptake, when canola was the test crop. This was probably due to low yield potential of canola at this site, especially in 2010 because of adverse weather conditions during the growing season.

In treatments where chemical fertilizers were also applied in addition to organic amendments, application of $\mathrm{N}$ fertilizer substantially increased seed yield, straw yield and nutrient uptake when in combination with both fine and granular wood ash treatments (especially fine wood ash), suggesting the lack of $\mathrm{N}$ in these treatments. Application of $\mathrm{N}$ in combination with glycerol also increased seed yield, straw yield and nutrient uptake, but crop yield and nutrient uptake were much less than with the gypsum $+\mathrm{N}+\mathrm{P}$ treatment, as discussed in following paragraph, suggesting the lack of both $\mathrm{N}$ and $\mathrm{S}$ in glycerol.

Earlier research has suggested that gypsum can be a suitable source of $\mathrm{S}$ to prevent $\mathrm{S}$ deficiency in grass when $\mathrm{N}$ is also applied [61]. Sulphur deficiency in canola can also be minimized and seed yield increased by proper application of elemental S fertilizers using broadcast spread/spray applications of fine particle elemental S as a suspension (or powder) on the surface of S-deficient soils [62]. Similarly, in our present study, the use of rapid release elemental $\mathrm{S}$ (RRES) granular along with $\mathrm{N}+\mathrm{P}$ fertilizers produced seed yield, straw yield and nutrient uptake similar to gypsum $+\mathrm{N}+\mathrm{P}$ treatment, and these two treatments produced seed yield, straw yield and nutrient uptake considerably higher than the unamended control. Based on the history of this site in relation to severe S deficiency in canola in previous years and considerable reduction in canola seed yield when only $\mathrm{N}$ was applied without any S fertilizer in 2010 and 2011, and also in previous years [45], it is possible that spring-applied RRES has the potential to provide available $S$ to the crop in the same growing season to the same level as gypsum or other sulphate-S sources. These results with mineral $\mathrm{S}$ sources suggest that gypsum and RRES can prevent $\mathrm{S}$ deficiency in organic crops, provided $\mathrm{N}$ and other nutrients are not lacking in soil.

This soil is extremely deficient in available $\mathrm{S}$, and has shown severe $\mathrm{S}$ deficiency in canola in the growing season and considerable reduction in canola seed yield when only $\mathrm{N}$ was applied without any $\mathrm{S}$ fertilizer. Based on the history of this site in relation to severe $\mathrm{S}$ deficiency in canola in the growing season in previous years [45] and our present results, the reduction in seed yield with only $\mathrm{N}$ application was most likely due to $\mathrm{N}$ and $\mathrm{S}$ imbalance in the plants $[63,64]$. Our results suggest the potential of 
gypsum and RRES in preventing $\mathrm{S}$ deficiency in organic crops when grown on S-deficient soils, provided other nutrients are not limiting in soil for crop growth. Our findings also suggest that RRES has the potential to prevent $\mathrm{S}$ deficiency in canola by providing available $\mathrm{S}$ to the crop in the growing season similar to gypsum, but seed yields of canola in our experiment were relatively lower than normal for this area, especially in 2010 and 2011. The lower than normal seed yields in our study were possibly because of the choice of a juncea canola cultivar in 2009, 2010 and 2011 (with relatively lower yield potential compared to hybrid canola), plus using moderate rate of $\mathrm{N}$ at $80 \mathrm{~kg} \cdot \mathrm{N} \cdot \mathrm{ha}^{-1}$, and very wet and cool weather conditions in 2012. In our other adjacent experiment, comparing granular RRES and sulphate S fertilizers applied in the previous autumn and in spring at seeding using various methods of placement on the same farm (with relatively high seed yield of hybrid canola grown at $120 \mathrm{~kg} \cdot \mathrm{N} \cdot \mathrm{ha}^{-1}$ ), spring applied RRES increased seed yield of canola compared to the zero-S control in the first year of application but seed yield was much less than sulphate-S fertilizer. Therefore, it is possible that under high seed yield conditions, spring applied sulphate-S may be more effective in increasing seed yield of canola than spring applied RRES, when broadcast/incorporated into soil in spring. In 2012, we replaced the juncea canola cultivar with a high yielding hybrid canola to find if RRES can be as effective as sulphate-S in preventing $\mathrm{S}$ deficiency in canola under high seed yield conditions. As mentioned earlier, that seed yield of hybrid canola in 2012 was lower than normal for this area, and the cumulative effect of RRES after four annual applications in increasing productivity, seed yield was almost similar to the similarly-applied sulphate-S fertilizer treatment in this study.

Research has shown that crops with deep taproots can absorb nutrients from deeper soil layers $[65,66]$. But, if the soil profileis low in available $\mathrm{P}$, then the only alternative is to add external $P$ source [67]. For example, the use of vesicular-arbuscularmychorrhiza (VAM), Penicillium bilaiae, rock phosphate, or bone meal can increase the release of $\mathrm{P}$ from soil and organic $\mathrm{P}$ fertilizers/amendments in order to prevent $\mathrm{P}$ deficiency in P-deficient soils and increase crop yields [52-54,57-59,68-70]. In a field study in Saskatchewan, Takeda [68] did not find any benefit of rock phosphate application on crop yield and $\mathrm{P}$ uptake over two years at any of three sites, but showed increases in crop yield and P uptake at two sites from the application of rock phosphate in combination with Penicillium bilaiae. Gleddie et al. [71] also reported positive responses to Penicillium bilaiae inoculation on soils that were extremely deficient in $\mathrm{P}$ for optimum growth. However, in our study, there was no effect of rock phosphate and/or Penicillium bilaiae on yield and P uptake of canola in any year, at this S-deficient site with also a potential of P-deficiency [46]. It is possible that the soil at this site may not be deficient in available $P$ to a level the may limit yield of canola because of its low yield, especially in 2010. We expected increase in crop yield and/or P uptake from the finely ground rock phosphate, because of the increase in surface area, but it did not happen. As explained earlier, this could be due to low yield potential of canola, and also possibly the released $\mathrm{P}$ from the fine rock phosphate fertilizer may have become again immobilized/fixed into the soil organic fraction due to greater microbial or chemical reaction of $\mathrm{P}$ in the finely ground rock phosphate in soil.

\section{CONCLUSION}

Some organic amendments showed potential for improvement in organic crop production, and in some other cases highest seed yields were obtained when both organic amendments and chemical fertilizers were applied together, or from combined application of chemical N, S and $\mathrm{P}$ fertilizers. These findings suggest that some organic amendments can be used to improve crop yields under organic production. These findings also suggest the potential of some inorganic amendments (e.g., rapid release elemental $\mathrm{S}$ and gypsum) in preventing $\mathrm{S}$ deficiency in organic crops, provided other nutrients are not limited in soil. The implications of these findings are that it may be possible to increase the sustainability of crop production by improving nutrient use and water use efficiency through better plant and root growth under both organic and conventional farming systems. It may also result in higher net returns to producers, improved soil quality, by returning more residues to soil, and minimize environmental damage of nitrate-N (leaching to ground water and nitrous oxide emissions), by leaving less residual nitrate- $\mathrm{N}$ in soils.

\section{ACKNOWLEDGEMENTS}

The authors thank Sulphur Solutions Inc. for financial assistance, Western Alfalfa for supplying alfalfa pellets, and D. Leach and K. Strukofffor technical assistance.

\section{REFERENCES}

[1] Entz, M.H., Guilford, R. and Gulden, R. (2001) Crop yield and soil nutrient status on 14 organic farms in the eastern part of the northern Great Plains. Canadian Journal of Plant Science, 81, 351-354. http://dx.doi.org/10.4141/P00-089

[2] Jans, D. (2001) Organic needs assessment: Results of workshops and questionnaires. Saskatchewan Agriculture and Food, Regina.

[3] Watson, C.A., Atkinson, P. Gosling, P., Jackson, L.R. and Ryans, F.W. (2002) Managing soil fertility in organic 
farming systems. Soil Use Manage, 18, 239-247. http://dx.doi.org/10.1079/SUM2002131

[4] Li, Y. and Lu, D. (1991) Effect of fertilization on wheat yield and its quality in wheat-producing region on Weibeirainfed highland. Agricultural Research in the Arid Areas, 2, 1-9.

[5] Li, S. and Zhao, B. (1991) Proposals for rational fertilization of arid soil in China. Chinese Journal of Soil Science, 22, 145-148.

[6] Laegreid M., Bockman O.C. and Kaarstad O. (1999) Agriculture, fertilizers and the environment. Norsk Hydro ASA, CABI Publishing, Porsgrunn, 113-139.

[7] Graham, P.H. and Vance, C.P. (2000) Nitrogen fixation in perspective: An overview of research and extension needs. Field Crops Research, 65, 93-106. http://dx.doi.org/10.1016/S0378-4290(99)00080-5

[8] Lai, Q., Li, C. and Huang, Q. (1992) Effect of continuous application of inorganic fertilizer on soil structure properties of paddy soil derived from red soil. Acta Pedologica Sinica, 29, 168-174.

[9] Doran, J.W., Sarrantonio, M. and Liebig, M.A. (1996) Soil health and sustainability. Advances in Agronomy, 56, 1-54. http://dx.doi.org/10.1016/S0065-2113(08)60178-9

[10] Beauchamp, E.G. (1983) Response of corn to nitrogen in pre-plant and side-dress applications of liquid dairy cattle manure. Canadian Journal of Soil Science, 63, 377-386. http://dx.doi.org/10.4141/cjss83-036

[11] Brinton, W.F. (1985) Nitrogen response of maize to fresh and composted manure. Biological Agriculture \& Horticulture, 3, 55-64. http://dx.doi.org/10.1080/01448765.1985.9754456

[12] Pang, X.P. and Letey, J. (2000) Organic farming: Challenge of timing nitrogen availability to crop nitrogen requirements. Soil Science Society of America Journal, 64, 247-253. http://dx.doi.org/10.2136/sssaj2000.641247x

[13] Schoenau, J.J., Bolton, K. and Panchuk, K. (2000) Managing manure as a fertilizer. SUSMMF1100, Saskatchewan Agriculture and Food, Regina.

[14] Qian, P. and Schoenau, J.J. (2000) Use of ion exchange membrane to assess soil $\mathrm{N}$ supply to canola as affected by addition of liquid swine manure and urea. Canadian Journal of Soil Science, 80, 213-218. http://dx.doi.org/10.4141/S99-049

[15] Qian, P. and Schoenau, J.J. (2002) Availability of nitrogen in solid manure amendments with different $\mathrm{C}: \mathrm{N}$ ratios. Canadian Journal of Soil Science, 82, 219-225. http://dx.doi.org/10.4141/S01-018

[16] Mooleki, S.P., Schoenau, J.J., Charles, J.L. and Wen, G. (2004) Effect of rate, frequency and incorporation of feedlot cattle manure on soil nitrogen availability, crop performance and nitrogen use efficiency in east-central Saskatchewan. Canadian Journal of Soil Science, 84, 199-210. http://dx.doi.org/10.4141/S02-045

[17] Schoenau, J.J. and Assefa, B. (2004) Land application and handling of manure. In: Amrani, M., Ed., Manure Research Findings and Technologies, AAFRD Technical Press, Edmonton, 97-140.

[18] Swift, M.J. and Woomer, P.L. (1993) Organic matter and sustainability of agricultural systems. Definition and measurement. In: Mulongoy, K. and Merckx, R., Eds., Soil Organic Matter Dynamics and Sustainability of Tropical Agriculture, John Wiley \& Sons, New York, 1-18.

[19] Bauer, A. and Black, A.L. (1994) Quantification of the effect of soil organic matter content on soil productivity. Soil Science Society of America Journal, 58, 185-193. http://dx.doi.org/10.2136/sssaj1994.03615995005800010 $\underline{027 x}$

[20] Milner, P.D., Silora, L.J., Kaufman, D.D. and Simpson, M.E. (1998) Agricultural uses of biosolids and other recyclable municipal residues. In: Wright, R.J., Kemper, W.D., Milner, P.D., Power, J.F. and Korcack, R.F., Eds., Agricultural Uses of Municipal, Animal and Industrial Byproducts, Conservation Research Report, 44, USDA, Agricultural Research Survey, Washington DC, 9-44.

[21] Korsaeth, A., Henriksen, T.M. and Bakken, L.R. (2002) Temporal changes in mineralization and immobilization of $\mathrm{N}$ during degradation of plant material: Implications for the plant $\mathrm{N}$ supply and $\mathrm{N}$ losses. Soil Biology and Biochemistry, 34, 789-799. http://dx.doi.org/10.1016/S0038-0717(02)00008-1

[22] Yang, S., Li, F., Malhi, S.S. Wang, P., Suo, D. and Wang, J. (2004) Long-term fertilization effects on crop yield and nitrate-N accumulation in soil in northwest China. Agronomy Journal, 96, 1039-1049.

http://dx.doi.org/10.2134/agronj2004.1039

[23] Akhtar, M., Naeem, A., Akhter, J., Bokhari, S.A. and Ishaque, W. (2011) Improvement in nutrient uptake and yield of wheat by combined use of urea and compost. Soil \& Environment, 30, 45-49.

[24] Harmsen, J., Velthorst, H.J. and Bennehey, I.P.A.M. (1994) Cleaning for residual concentration with an extensive form of land forming. In: Hinchee, R.E., Anderson, D.B., Melting Jr., F.B. and Sayles, G.D., Eds., Applied Boitechnology for Site Remediation, Lewis Publishers, Boca Raton, 84-91.

[25] Lin, B., Lin, J. and Li, J. (1996) Changes of crop yield and soil fertility by long-term fertilization. Chinese Agriculture Science and Technology Press, Beijing, 26-90.

[26] Matson, P.A., Naylor, R. and Monasterio, I.O. (1998) Integration of environmental, agronomic, and economic aspects of fertilizer management. Science, 280, 112-115. http://dx.doi.org/10.1126/science.280.5360.112

[27] Yang, S., Malhi, S.S., Song, J.R., Yue, W.Y., Wang, J.G. and Guo, T.W. (2006) Crop yield, N uptake and nitrate-N accumulation in soil as affected by 23 annual applications of fertilizers and manure on in the rainfed region of northwestern China. Nutrient Cycling in Agroecosystems, 76, 81-94. http://dx.doi.org/10.1007/s10705-006-9042-x

[28] Hu, Y. and Schmidhalter, U. (2005) Drought and salinity: A comparison of their effects on mineral nutrition of plants. Journal of Plant Nutrition and Soil Science, 168, 541-549. http://dx.doi.org/10.1002/jpln.200420516

[29] Ahmad, R., Khalid, A., Arshad, M., Zahir, Z.A. and Naveed, M. (2006) Effect of raw (un-composted) and composted organic waste on growth and yield of maize (Zea mays L.). Soil \& Environment, 25, 135-142. 
[30] Ahmad, R., Naveed, M., Aslam, M., Zahir, Z.A., Arshad, M. and Jilani, G. (2008) Economizing the use of nitrogen fertilizer in wheat production through enriched compost. Renewable Agriculture and Food Systems, 23, 243-249. http://dx.doi.org/10.1017/S1742170508002299

[31] Hoyt, P.B. and Leitch, R.H. (1983) Effects of forage legume species on soil moisture, nitrogen, and yield of succeeding barley crops. Canadian Journal of Soil Science, 63, 125-136. http://dx.doi.org/10.4141/cjss83-012

[32] Foster, R.K. (1990) Effect of tillage implement and date of sweetclover incorporation on available soil $\mathrm{N}$ and succeeding spring wheat yields. Canadian Journal of Plant Science, 70, 269-277.

http://dx.doi.org/10.4141/cjps90-029

[33] Townley-Smith, L., Slinkard, A.E., Bailey, L.D., Biederbeck, V.O. and Rice W.A. (1993) Productivity, water use and nitrogen fixation of annual legume green-manure crops in the Dark Brown soil zone of Saskatchewan. Canadian Journal of Plant Science, 73, 139-148.

[34] Brandt, S., Johnson, E., Malhi, S.S., Zentner, R., Thomas, G. and Olfert, O. (2007) Organic cropping in the semi-arid prairies: Opportunities, challenges and progress. In: Proceedings of Plant Canada 2007 Conference, Saskatoon, 80-81. http://www.plantcanada.ca/eng/conference.htm

[35] Zentner, R.P., Campbell, C.A., Biederbeck, V.O. and Selles, F. (1996) Indianhead black lentil as green manure for wheat rotations in the Brown soil zone. Canadian Journal of Plant Science, 76, 417-422. http://dx.doi.org/10.4141/cjps96-074

[36] Zentner, R.P., Campbell, C.A., Biederbeck, V.O., Selles, F., Lemke, R., Jefferson, P.G. and Gan, Y. (2004) Longterm assessment of management of an annual legume green manure crop for fallow replacement in the brown soil zone. Canadian Journal of Plant Science, 84, 11-22. http://dx.doi.org/10.4141/P02-188

[37] Buhler, R.S. (2005) Influence of management practices on weed communities in organic cereal production systems in Saskatchewan. Master's Thesis, University of Saskatchewan, Saskatoon.

[38] Chae, Y.M. and Tabatabai, M.A. (1986) Mineralization of nitrogen in soils amended with organic manure. Journal of Environmental Quality, 15, 193-198. http://dx.doi.org/10.2134/jeq1986.00472425001500020021x

[39] Araji, A.A., Abdo, Z.O. and Joyce, P. (2001) Efficient use of animal manure on cropland-Economic analysis. Bioresource Technology, 79, 179-191.

[40] Fleming, R.A. and Long, J.D. (2002) Measuring cost of restricting access to cropland for manure nutrient management. Agronomy Journal, 94, 57-64. http://dx.doi.org/10.2134/agronj2002.0057

[41] Whalen, J.K. and Chang, C. (2002) Phosphorus sorption capacities of calcareous soils receiving cattle manure applications for 25 years. Communications in Soil Science and Plant Analysis, 33, 1011-1026.

http://dx.doi.org/10.1081/CSS-120003870

[42] Feinerman, E., Bosch, D. J. and Pease, J.W. (2004) Manure applications and nutrient standards. American Journal of Agricultural Economics, 86, 14-25.

http://dx.doi.org/10.1111/j.0092-5853.2004.00559.x
[43] Ribaudo, M., Cattaneo, A. and Agopoff, J. (2004) Cost of meeting manure nutrient standards in hog production: The roles of EQIP and fertilizer offsets. Review of Agricultural Economics, 26, 430-444. http://dx.doi.org/10.1111/j.1467-9353.2004.00192.x

[44] Keplinger, K.O. and Hauck, L.M. (2006) The economics of manure utilization: Model and application. Journal of Agricultural and Resource Economics, 31, 414-440.

[45] Malhi, S.S., Gan, Y. and Raney, J.P. (2007) Yield, seed quality, and sulfur uptake of Brassica oilseed crops in response to sulfur fertilization. Agronomy Journal, 99, 570577. http://dx.doi.org/10.2134/agronj2006.0269

[46] Malhi, S.S., Coulman, B. and Schoenau, J.J. (2009) Maximizing timothy forage yield and quality by balanced nitrogen, phosphorus and sulphur fertilization. Agronomy Journal, 101, 1182-1189. http://dx.doi.org/10.2134/agronj2009.0051

[47] Noel, R.J. and Hambleton, L.G. (1976) Collaborative study of a semi-automated method for the determination of crude protein in animal feeds. Journal of the Association of Official Analytical Chemists, 59, 134-140.

[48] Milbury, W.F., Stack, V.T. and Doll, F.L. (1970) Simultaneous determination of total phosphorus and total Kjeldahl nitrogen in activated sludge with the Technicon continuous digestor system. Volume 2 of Advances in Automated Analysis: Technicon (5th) International Congress 1970, New York, 2-4 November 1970, 299-304.

[49] Varley, J.A. (1966) Automated method for the determination of nitrogen, phosphorus and potassium in plant material. Analyst, 91, 119-126. http://dx.doi.org/10.1039/an9669100119

[50] Jones, J.B. (1991) Plant Tissue Analysis in Micronutrients. SSSA, Chapter 13, Micronutrients in Agriculture, 2nd Edition, Questron Technologies Corp., Mississauga.

[51] SAS Institute Inc. (2004) Online documentation for SAS, version 8.

http://support.sas.com/documentation/onlinedoc/index.ht $\underline{\mathrm{ml}}$

[52] Kucey, R.M.N. (1983) Phosphate-solubilizing bactera and fungi in various cultivated and virgin Alberta soils. Canadian Journal of Soil Science, 63, 671-678. http://dx.doi.org/10.4141/cjss83-068

[53] Kucey, R.M.N. (1987) Increased phosphorus uptake by wheat and field beans inoculated with a phosphorussolubilizing Penicillium bilaji strain and with vesiculararbuscular Mycorrhizal fungi. Applied and Environmental Microbiology, 53, 2699-2703.

[54] Kucey, R.M.N. and Leggett, M.E. (1989) Increased yields and phosphorus uptake by Westar canola (Brassica napus L.) inoculated with a phosphate-solubilizing isolate of Penicillium bilaji. Canadian Journal of Soil Science, 69, 425-432. http://dx.doi.org/10.4141/cjss89-042

[55] Hnatowich, G.L., Gleddie, S.C. and Polonenko, D.R. (1990) Wheat response PB-50 (Penicillium bilaji), a phosphateinoculant. Proceedings of the Great Plains Soil Fertility Conference, Denver, 6-7 March 1990, 235.

[56] Blackshaw, R.E. (2005) Nitrogen fertilizer, manure, and compost effects on weed growth and competition with 
spring wheat. Agronomy Journal, 97, 1612-1621. http://dx.doi.org/10.2134/agronj2005.0155

[57] Chalk, P.M., Souze, R. de F., Urquiaga, B.J.R. and Boddey, R.M. (2006) The role of arbuscular mychorrhiza in legume sybiotic performance. Soil Biology \& Biochemistry, 38, 2944-2951.

http://dx.doi.org/10.1016/j.soilbio.2006.05.005

[58] Jeng, A.S., Haraldsen, T.K., Gronlund, R. and Pedersen, P.A. (2009) Meat and bone meal as nitrogen and phosphorus fertilizer to cereals and ryegrass. Nutrient Cycling in Agroecosystems, 76, 183-191. http://dx.doi.org/10.1007/s10705-005-5170-y

[59] Rick, T.L., Jones, C.A., Engel, R.E. and Miller, P.R. (2007) Ability of a green manure crop to increase availability of organic phosphorus fertilizers. ASA-CSSA-SSSA International Annual Meetings, New Orleans, 4-8 November 2007.

[60] Enwezor, W.O. (1976) The mineralization of nitrogen and phosphorus in organic materials of varying $\mathrm{C}: \mathrm{N}$ and $\mathrm{C}: \mathrm{P}$ ratios. Plant Soil, 44, 237-240. http://dx.doi.org/10.1007/BF00016972

[61] Malhi, S.S., Heier, K. and Solberg, E. (2000) Effectiveness of elemental $\mathrm{S}$ fertilizers on forage grasses. Canadian Journal of Plant Science, 80, 105-112. http://dx.doi.org/10.4141/P99-002

[62] Malhi, S.S., Solberg, E.D. and Nyborg, M. (2005) Influence of formulation of elemental S fertilizer on yield, quality and S uptake of canola seed. Canadian Journal of Plant Science, 85, 793-802. http://dx.doi.org/10.4141/P04-134

[63] Nyborg, M., Bentley, C.F. and Hoyt, P.B. (1974) Effect of sulphur deficiency. Sulphur Institute Journal, 10, 14-15.

[64] Janzen, H. H. and Bettany, J. R. (1984) Sulfur nutrition of rapeseed. I. Influence of fertilizer nitrogen and sulfur rates. Soil Science Society of America Journal, 48, 100107.

http://dx.doi.org/10.2136/sssaj1984.03615995004800010 $\underline{019 x}$

[65] Entz, M.H., Bullied, W.J., Foster, D.A., Gulden, R. And Vessey, K. (2001) Extraction of subsoil nitrogen by alfalfa, alfalfa-wheat and perennial grass systems. Agronomy Journal, 93, 495-503. http://dx.doi.org/10.2134/agronj2001.933495x

[66] Merrill, S.D., Tanaka, D.L. and Hanson, J.D. (2002) Root length growth of eight crop species in haplustoll soils. Soil Science Society of America Journal, 66, 913-923. http://dx.doi.org/10.2136/sssaj2002.0913

[67] Malhi, S.S., Brandt, S.A., Ulrich, D., Lemke, R. and Gill, K.S. (2002) Accumulation and distribution of nitrate-nitrogen and extractable phosphorus in the soils profile under various alternative cropping systems. Journal of Plant Nutrition, 25, 2499-2520. http://dx.doi.org/10.1081/PLN-120014709

[68] Takeda, M. (2004) Solubilization of rock phosphate by Penicillium bilaiae: Mechanisms and the feasibility for use in organic crop production. Master's Thesis, University of Saskatchewan, Saskatoon.

[69] Walker, R.L., Wattson, C.A., Rees, R.M. and Stockdale, E.A. (2006) Managing soil fertility in organic farming sytems. Aspects of Applied Biology, 79, 300-315.

[70] Rick, T.L. (2009) Phosphorus fertility in Northern Great Plains dryland organic cropping systems. Master's Thesis, Montana State University, Bozeman.

[71] Gleddie, S.C., Schlechte, D. and Turnbull, G. (1993) Effect of inoculation with Penicillium bilaii (Provide ${ }^{\circledR}$ ) on phosphate uptake and yield of canola in western Canada. Proceedings of Alberta Soil Science Workshop, Edmonton, February 1993, 155-160. 